\title{
Mechanisms of simvastatin myotoxicity: The role of autophagy flux inhibition.
}

Arya Emami

University of Manitoba

Shahla Shojaei

University of Manitoba

Simone C. da Silva Rosa

University of Manitoba; Children's Hospital Research Institute of Manitoba

Mahmoud Aghaei

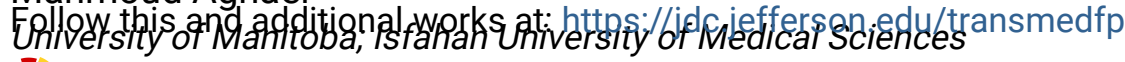

Part of the Cardiology Commons, Other Pharmacology, Toxicology and Environmental Health

Ehsan Samiei

Eniversitys of wictorialogy Commons, and the Translational Medical Research Commons

Let us know how access to this document benefits you

\section{See next page for additional authors}

\section{Recommended Citation}

Emami, Arya; Shojaei, Shahla; da Silva Rosa, Simone C.; Aghaei, Mahmoud; Samiei, Ehsan;

Vosoughi, Amir Reza; Kalantari, Forouh; Kawalec, Philip; Thliveris, James; Sharma, Pawan; Zeki, Amir A.; Akbari, Mohsen; Gordon, Joseph W.; and Ghavami, Saeid, "Mechanisms of simvastatin myotoxicity: The role of autophagy flux inhibition." (2019). Center for Translational Medicine Faculty Papers. Paper 63.

https://jdc.jefferson.edu/transmedfp/63

This Article is brought to you for free and open access by the Jefferson Digital Commons. The Jefferson Digital Commons is a service of Thomas Jefferson University's Center for Teaching and Learning (CTL). The Commons is a showcase for Jefferson books and journals, peer-reviewed scholarly publications, unique historical collections from the University archives, and teaching tools. The Jefferson Digital Commons allows researchers and interested readers anywhere in the world to learn about and keep up to date with Jefferson scholarship. This article has been accepted for inclusion in Center for Translational Medicine Faculty Papers by an authorized administrator of the Jefferson Digital Commons. For more information, please contact: JeffersonDigitalCommons@jefferson.edu. 


\section{Authors}

Arya Emami, Shahla Shojaei, Simone C. da Silva Rosa, Mahmoud Aghaei, Ehsan Samiei, Amir Reza Vosoughi, Forouh Kalantari, Philip Kawalec, James Thliveris, Pawan Sharma, Amir A. Zeki, Mohsen Akbari, Joseph W. Gordon, and Saeid Ghavami 
$3 \quad{ }^{1 ¥}$ Arya Emami, ${ }^{1 ¥}$ Shahla Shojaei, ${ }^{1,2 ¥}$ Simone C da Silva Rosa, ${ }^{1,3}$ Mahmoud Aghaei, ${ }^{4}$ Ehsan

4 Samiei, ${ }^{1}$ Amir Reza Vosoughi, ${ }^{1}$ Forouh Kalantari, ${ }^{1}$ Philip Kawalec, ${ }^{1}$ James Thliveris, ${ }^{5}$ Pawan

5 Sharma, ${ }^{6,7,8}$ Amir A Zeki, ${ }^{4}$ Mohsen Akbari, $* 1,2,12$ Joseph W. Gordon, $* 1,8,9,10$ Saeid Ghavami

$6 \quad{ }^{1}$ Department of Human Anatomy \& Cell Science, Max Rady College of Medicine, Rady Faculty of 7 Health Sciences, University of Manitoba, Winnipeg, MB, Canada.

8 2Diabetes Research Envisioned and Accomplished in Manitoba (DREAM) Theme, Children's Hospital 9 Research Institute of Manitoba, Winnipeg, MB, Canada.

${ }^{3}$ Department of Clinical Biochemistry, School of Pharmacy \& Pharmaceutical Sciences, Isfahan University of Medical Sciences, Isfahan, Iran.

${ }^{4}$ Laboratory for Innovations in Microengineering (LiME), Department of Mechanical Engineering, University of Victoria, Victoria, BC V8P 5C2, Canada; Centre for Advanced Materials and Related Technologies (CAMTEC), University of Victoria, Victoria, BC, V8P 5C2, Canada; Centre for Biomedical Research (CBR), University of Victoria, Victoria, BC, V8P 5C2, Canada.

${ }^{5}$ Thomas Jefferson University, 1020 Locust Street, Philadelphia, PA USA 19107.

${ }^{6}$ University of California, Davis. Department of Internal Medicine. Division of Pulmonary, Critical Care, and Sleep Medicine, Sacramento, CA.

${ }^{7}$ Veterans Affairs Medical Center, Mather, CA.

${ }^{8}$ Center for Comparative Respiratory Biology and Medicine, Davis, CA.

${ }^{9}$ Children's Hospital Research Institute of Manitoba, Winnipeg, MB, Canada.

${ }^{10}$ Research Institute of Oncology and Hematology, CancerCare Manitoba, University of Manitoba, Winnipeg, Canada.

${ }^{11}$ Autophagy Research Center, Health Policy Research Centre, Shiraz University of Medical Science, 25 Shiraz, Iran.

${ }^{12}$ College of Nursing, Rady Faculty of Health Sciences, University of Manitoba, Winnipeg, MB, Canada.

27 *These authors have senior authorship

$¥$ These authors have equal first authorship

Address for Correspondence: Saeid Ghavami, Department of Human Anatomy \& Cell Science, Max Canada. Email: saeid.ghavami@umanitoba.ca

Key words: statin, autophagy flux, prenylation, 3D culture mode 
Statins are some of the most widely used drugs worldwide, but one of their major side effects is myotoxicity. Using mouse myoblast (C2C12) and human alveolar rhabdomyosarcoma

37 cell lines (RH30) in 2-dimensional (2D) and 3-dimensional (3D) culture, we investigated the mechanisms of simvastatin's myotoxicity. We found that simvastatin significantly reduced cell 39 viability in $\mathrm{C} 2 \mathrm{C} 12$ cells compared to $\mathrm{RH} 30$ cells. However, simvastatin induced greater apoptosis in RH30 compared to C2C12 cells. Simvastatin-induced cell death is dependent on

41 Geranylgeranyl pyrophosphate (GGPP) in C2C12 cells, while in RH30 cells it is dependent on 42 both Farnesyl pyrophosphate (FPP) and GGPP. Simvastatin inhibited autophagy flux in both $43 \mathrm{C} 2 \mathrm{C} 12$ and RH30 cells and inhibited lysosomal acidification in C2C12 cells, while autophagy 44 inhibition with Bafilomycin-A1 increased simvastatin myotoxicity in both cell lines. Simvastatin 45 induced more cell death in RH30 cells compared to C2C12 in 3D culture model with similar 46 effects on autophagy flux as in 2D culture. Overall our results suggest that simvastatin-induced 47 myotoxicity involves both apoptosis and autophagy, where autophagy serves a pro-survival role 48 in both cell lines. The sensitivity to simvastatin myotoxicity is different in $2 \mathrm{D}$ versus $3 \mathrm{D}$ culture, 49 demonstrating that the cellular microenvironment is a critical factor in regulating simvastatin50 induced cell death in myoblasts. 
The statin drugs ('statins') are competitive inhibitors of HMG-CoA (3-hydroxy-3methylgutarylcoenzyme A) reductase, and thus attenuate cholesterol and isoprenoid biosynthesis in the mevalonate (MA) pathway (Endo et al., 1977). They are used clinically as lipid-lowering drugs that prevent and treat cardiovascular diseases including atherosclerosis, coronary artery 61 disease, and stroke (Grundy and Vega, 1985; Illingworth and Sexton, 1984; Tikkanen and 62 Nikkila, 1987). The MA pathway is an essential contributor to mammalian cell homeostasis, as it 63 is involved in the regulation of a multitude of cellular processes that require cholesterol and the 64 isoprenoid intermediates (Cartocci et al., 2017; Hashemi et al., 2017). Cholesterol is the final 65 sterol product of the MA cascade but several upstream isoprenoid metabolites including Farnesyl pyrophosphate (FPP) and Geranylgeranyl pyrophosphate (GGPP) are necessary for the

67 prenylation of monomeric small GTPase proteins (e.g. Rho, Ras, Rac, Cdc42, Rab, Rap) 68 (Hashemi et al., 2017; Sheikholeslami et al., 2019). These prenylated GTPases are critical cell 69 signaling molecules involved in many basic cellular processes including proliferation, growth, 70 migration, cytoskeletal dynamics, vesicular trafficking, barrier integrity, and smooth muscle 71 contraction, to name a few. Thus, the MA pathway is tightly regulated to maintain these precise 72 cellular functions under varied conditions in many cell types critical to health and disease (Jiao et 73 al., 2017; Yeganeh et al., 2014).

Statins are generally well-tolerated medications, however, there are side effects associated with these compounds which are dose-dependent. One of the most important and clinically 76 relevant side effects is skeletal muscle myopathy which occurs in 1-5\% of patients who take 77 statins. Rarely, this can lead to lethal rhabdomyolysis if it is not diagnosed promptly (Ballantyne 78 et al., 2003; Graham et al., 2004; Staffa et al., 2002; Thompson et al., 2003). According to recent 
79 investigations, statin-related muscle disorders are potentially dependent on the inhibition of FPP 80 and GGPP (Bhardwaj et al., 2013; Matzno et al., 1997). Treatment of C2C12 cells with GGPP

81 can reverse the inhibitory effects of statins on myotube formation (Baba et al., 2008). In support 82 of these findings, there is evidence that statin-induced muscle toxicity is connected to the 83 inhibition of protein geranylgeranylation (Johnson et al., 2004), where prenylation of small 84 GTPases is essential to their signaling function, including RAP GTPase. This reaction 85 exclusively requires geranylgeranylation of RAP1A small Rho-GTPase protein, which is 86 catalyzed by the prenyltransferases (Crick et al., 1997). Although these investigations have been 87 illuminating regarding statin-induced muscle toxicity, the exact mechanisms underlying this 88 phenomenon remain incompletely understood. Macroautophagy (hereafter listed as autophagy) is a multi step "self-eating" physiological process that regulates cellular response to stress (Amiri et al., 2019). Autophagy can be involved 91 in both survival and death mechanisms based on the type of the cells and stimuli (Hombach92 Klonisch et al., 2018; Mokarram et al., 2017). Once it has been induced, tightly regulated 93 sequential steps direct the formation of a bilayer vesicle called the autophagosome to consume 94 cytoplasmic cargo (Klionsky et al., 2016; Mehrbod et al., 2019). This cargo is then ubiquitinated 95 and recognized by autophagy receptors like p62. The cargo receptor later binds to the cargo and 96 LC3-II, a component of the autophagosome membrane, which facilitates the isolation of the 97 cargo and its delivery to lysosomes. Autophagy can be involved in regulation of programmed cell death I (apoptosis) under 99 different scenarios: i) as a positive controller (autophagy increases apoptosis), ii) as a negative 100 controller (autophagy decreases apoptosis), or iii) parallel to apoptosis (autophagy does not 101 change cellular apoptosis) (Ghavami et al., 2010a; Ghavami et al., 2010b; Ghavami et al., 2012a; 
102 Ghavami et al., 2011; Ghavami et al., 2014; Ghavami et al., 2012b; Liu et al., 2017; Song et al., 103 2017). Investigators have used autophagy and apoptosis cross regulation to develop new 104 therapeutic approaches for cancer. For example, different autophagy inducers and inhibitors have 105 been used with chemotherapy agents, and radiotherapy to increase the efficiency of cancer 106 therapy in some patients (Hombach-Klonisch et al., 2018; Mokarram et al., 2017).

107 We have previously studied cell death mechanisms of statins in airway smooth muscle and 108 recently established a research program in developing new therapeutic approaches for 109 Rhabdomyosarcoma (RMS). Previous investigations have used C2C12 mouse myoblasts 110 (Jaskiewicz et al., 2019; Schirris et al., 2015a) as a model for investigation of statins myopathy. 111 In the current study, we aim to understand the myotoxic effects of statins, using the 112 rhabdomyosarcoma cell line (RH30) (Moghadam et al., 2018) as well as C2C12 cell lines to 113 address this clinically relevant question. 
124 simvastatin (S6196), FPP (F6892), GGPP (G6025), cholesterol (47129), mevalonate (68519),

125 LC3 $\beta$ antibody (L7543), and beta actin antibody (A2228) were purchased from Sigma/Aldrich

126 (Canada, Ontario) Dimethyl sulfoxide (DMSO) (4948-02) were purchased from VWR (Canada,

127 Ontario). SQSTM1/p62 antibody (5114) were purchased from cell singling (Canada Ontario).

128 Cleaved PARP (Asp214) (D64E10) XP® Rabbit mAb, LC3B (D11) XP® Rabbit mAb, and 129 SQSTM1/p62 (D5L7G) Mouse mAb were purchased from Cell Signaling Technology. Alexa 130 Fluor ${ }^{\circledR} 488$ AffiniPure Donkey Anti-Rabbit IgG, and Alexa Fluor® 647 AffiniPure Donkey 131 Anti-Mouse IgG secondary antibodies and IgG-free bovine serum albumin (BSA) were 132 purchased from Jackson ImmunoResearch Inc. DAPI (4',6-Diamidino-2-Phenylindole, 133 Dihydrochloride) was purchased from Thermo Fisher Scientific. Bovine type 1 collagen (10 $134 \mathrm{mg} / \mathrm{mL}$ ) was purchased from Advanced BioMatrix Inc. Live/dead viability staining kit was 135 purchased from Millipore Sigma.

\section{Cell Lines and Cell Culture}

The human rhabdomyosarcoma cell line (RH30) [RC13, RMS 13, SJRH30] (ATCC®

$139 \mathrm{CRL} \neg 2061^{\mathrm{TM}}$ ) (Human muscle cancer cells) and mouse muscle cell line (C2C12) (ATCC® $140 \mathrm{CRL} \neg 1772^{\mathrm{TM}}$ ) were used in this project. Cells were cultured in Roswell Park Memorial Institute 141 (RPMI- 1640) with L-glutamine and 25mM HEPES (BioWhittaker; Cat \#: 12-115Q) and 142 Dulbecco's Modified Eagle's Medium (DMEM) (CORNING; Cat \#: 50-003-PB) with 10\% fetal 143 bovine serum (FBS) (Gibco ${ }^{\mathrm{TM}}$; Cat \#: 16000044). RH30 cell lines were cultured in RPMI-1640 144 with L-glutamine and $25 \mathrm{mM}$ HEPES media, and C2C12 cells were cultured in DMEM with 145 high glucose media. Both media were supplemented with FBS (10\%), penicillin (1\%), and 
146 streptomycin (1\%). Cells were grown to $35-40 \%$ confluency on a $100 \mathrm{~mm}$ cell culture plate, 6147 well plates, and 96-well plates. Cells were maintained in a humidified incubator with 95\% air 148 and $5 \% \mathrm{CO} 2$ at $37{ }^{\circ} \mathrm{C}$ and were passed once every 2-3 days. Cell culture plastic ware, penicillin, 149 and streptomycin were purchased from VWR (Toronto, ON, Canada).

MTT Assay

The MTT assay was performed based on a protocol established in our group (Alizadeh et 153 al., 2017; Ghavami et al., 2004; Ghavami et al., 2010b; Ghavami et al., 2012a; Ghavami et al., 154 2011; Ghavami et al., 2014). Briefly C2C12 (20,000 cells/mL) and RH30 (30,000 cells/mL) were 155 seeded in 96-well plates and treated with varying concentrations of simvastatin (Simva, 0-20 156 $\mu \mathrm{M})$. At each time-point (24, 48, 72, and $96 \mathrm{hrs}), 20 \mu \mathrm{L}$ of (MTT, $5 \mathrm{mg} / \mathrm{ml})$ was added to each

157 well. The cells were incubated at $37^{\circ} \mathrm{C}$ for 4 hours, after which the media was gently aspirated. 158 Then, $200 \mu \mathrm{L}$ of DMSO was added to each well and mixed with the cells by pipetting to dissolve 159 the MTT formazan crystals. Lastly, the plates were incubated for $20 \mathrm{~min}$ at room temperature. Absorbance was measured at $570 \mathrm{~nm}$ using a Synergy H1 Microplate Reader.

Mevalonate Cascade Rescue Assay

Rescue experiments were done according to previously reported protocols (Alizadeh et 164 al., 2017; Ghavami et al., 2012a; Ghavami et al., 2011; Ghavami et al., 2014). Briefly, cells 165 were seeded and grown in 96-well plates at a density of 2,000 cells per well, up to $50 \%$ 166 confluence. Cells were pre-treated with $5 \mathrm{mM}$ mevalonate $(\mathrm{MeV}), 30 \mu \mathrm{M}$ FPP, $30 \mu \mathrm{M}$ GGPP, 167 and $50 \mu \mathrm{M}$ cholesterol, and were incubated at $37^{\circ} \mathrm{C}$ for $4 \mathrm{hrs}$. These cells were then co-treated 
with $10 \mu \mathrm{M}$ Simvastatin and incubated at $37^{\circ} \mathrm{C}$ for $96 \mathrm{hrs}$. Cell viability was then measured using the MTT assay after $96 \mathrm{hrs,}$ as described in the previous section.

\section{Immunoblotting}

Western blotting analysis of $\mathrm{C} 2 \mathrm{C} 12$ and $\mathrm{RH} 30$ cell lysates was used to assess markers of autophagy (LC3 (1:2500), p62 (1:1000)) as has been described in our previous studies (Ghavami et al., 2010b; Ghavami et al., 2012a; Ghavami et al., 2011; Ghavami et al., 2014). Cells were grown to $40-50 \%$ confluency in $100 \mathrm{~mm}$ dishes and either treated with $10 \mu \mathrm{M}$ Simva or with a drug vehicle control (DMSO). At the appropriate time point, cells were collected, and protein extracts were made using NP-40 Lysis Buffer (0.5\% (v/v) Nonidet P-40, 20 mM Tris- $\mathrm{HCl}(\mathrm{pH}$ 7.5), 0.5\% (v/v) PMSF, $100 \mu \mathrm{M} \beta$-glycerol 3-phosphate and 1.5\% (v/v) protease inhibitor cocktail). Once the protein concentration was known, samples were prepared for western blotting with a total protein concentration of $1 \mu \mathrm{g} / \mu \mathrm{L}$ (15 $\mu \mathrm{L}$ of each sample was used). After electrophoresis, the membranes were developed for $\mathrm{LC} 3 \beta$ and $\mathrm{p} 62$ proteins.

\section{Measurement of Apoptosis with Flow Cytometry}

We measured apoptosis using the Nicoletti method. $\mathrm{C} 2 \mathrm{C} 12$ and RH30 cells were cultured in 6-well plates and treated with either Simva $(5$ or $10 \mu \mathrm{M})$ or with a drug vehicle control (DMSO) for 48 hrs. After drug treatment, cells were detached using EDTA buffer and centrifuged at $1,500 \times g$ for $5 \mathrm{~min}$ at $4^{\circ} \mathrm{C}$. Cells were washed with cold PBS before they were permeabilized and stained with a hypotonic Propidium Iodide (PI) buffer (0.1\% Triton X-100, $1 \%$ sodium citrate, $0.5 \mathrm{mg} / \mathrm{ml}$ RNase A, $40 \mu \mathrm{g} / \mathrm{ml}$ propidium iodide). Samples were then incubated for 1 hour in the dark at $4^{\circ} \mathrm{C}$ to prevent photo-bleaching. Flow cytometry was carried 
191 out at $460 \mathrm{~nm}$ for 10,000 cells. Residual debris were gated out accurately to obtain accurate data.

192 The resulting histogram was analyzed to determine the percentage of normal and apoptotic

193 nuclei; the nuclei of apoptotic cells were located on the left side of the G1 peak as they have less

194 DNA compared to the nuclei of healthy G0/G1 cells. For each sample, the sub-G1 peak was 195 measured and statistically compared with other samples to determine significance (Hashemi et 196 al., 2007; Moghadam et al., 2018).

Live Cell Imaging

199 LC3 is a specific marker for autophagosomes, which are key structures in the process of 200 autophagy. LC3-GFP is a fusion of green fluorescent protein (GFP) and LC3, and it can behave 201 in the same manner as endogenous LC3. LC3-GFP is localized on the autophagosome membrane 202 and emits green light when excited. In a normal cell, LC3 is dispersed evenly through the 203 cytosol. However, when autophagic flux is initiated, LC3 is recruited to autophagosome 204 membranes, resulting in sharp green puncta and LC3-GFP-containing cells. To confirm 205 autophagy findings seen in western blots, C2C12 or RH30 cells were grown in 6-well plates and 206 transfected with a plasmid containing LC3-GFP (Addgene \#24920) using Qiagen's Effectene 207 reagent, as per manufacturer's instructions. After transfecting cells for 18 hrs, the cells were 208 treated with either Simva $(10 \mu \mathrm{M})$, Bafilomycin-A1 (Baf-A1, $100 \mathrm{nM})$, Simva + Baf-A1, or a 209 vehicle control (DMSO). After 24 hrs, the cells were incubated with LysoTracker red dye 210 (Molecular Probes; LysoTracker Red DND-99; L7528) at a concentration of $50 \mathrm{nM}$ to detect 211 lysosomal activity and counterstained with Hoechst. Cells were stained for 30 min in a $37^{\circ} \mathrm{C}$ 212 incubator. After the 30 min period, the cells were washed with PBS and fresh media was added. 213 The cells were imaged on an epifluorescence microscope. Images were analyzed to determine the 
214 percentage of cells with distinct LC3-GFP puncta and to see if green and red puncta co-

215 localization had occurred, which was assumed to signify the fusion of autophagosomes with 216 lysosomes (Field et al., 2018; Moghadam et al., 2018).

Transmission Electron Microscopy (TEM)

TEM was used to evaluate autophagy in both $\mathrm{C} 2 \mathrm{C} 12$ and RH30 cell lines. The TEM 220 protocol is the same as previously described ${ }^{1}$. Briefly, cells were grown in $10 \mathrm{~mm}$ dishes $221(300,000$ cells/dish) and treated with either DMSO (drug vehicle control) or $10 \mu \mathrm{M}$ Simva for 48 222 hrs. At the time point, cells were detached with EDTA and centrifuged at 1,500×g. The samples 223 were then fixed with $3 \%$ glutaraldehyde in PBS ( $\mathrm{pH} 7.4)$ for 3 hrs at room temperature. The 224 samples were later treated post-fixation with $1 \%$ osmium tetroxide in PBS for 2 hrs, followed by 225 an alcohol dehydration series, and then embedded in Epon and stained with uranyl acetate. They 226 were counterstained with lead citrate for 3 min sequentially and finally washed with water for 1 227 min and dried. The samples were imaged on a Philips CM10 at $80 \mathrm{kV}$ on ultra thin sections 228 (100nm on 200 mesh grids) (Alizadeh et al., 2018a; Moghadam et al., 2018).

\section{Culturing C2C12 and RH3O cells in 3D cultures}

C2C12 and RH30 cells were grown in 3D culture according to the same protocol 232 explained in previous publications (Moghadam et al., 2018). Briefly, cells were grown in culture 233 medium (DMEM or RPMI with $10 \%$ FBS and $0.5 \%$ Pen-Strep) until they reached $80 \%$ 234 confluency. Cells were detached with Trypsin-EDTA, spun down, and re-suspended in fresh 235 media. Collagen and media were gently added to the cell suspension at $4^{\circ} \mathrm{C}$ to reach a final 236 collagen concentration of $3 \mathrm{mg} / \mathrm{mL}$ and a cell density of 2 million cells/mL. Then, $20 \mu \mathrm{L}$ of this 
237 solution was added to cylindrical wells with $5 \mathrm{~mm}$ diameter and $1 \mathrm{~mm}$ depth in PDMS holders

238 which were placed in 12 well-plates and put in a $37^{\circ} \mathrm{C}$ incubator for $45 \mathrm{~min}$ to cure the collagen.

239 Afterwards, $2 \mathrm{~mL}$ of media was added to each well and they were incubated overnight. The next

240 day, cells were treated with either DMSO or Simva (Moghadam et al., 2018).

241

242

Live-Dead Assay in 3D Culture

243

Cells were grown and treated as explained above. Live-dead assay solution was prepared

244 as per the supplier's instructions, where $5 \mu \mathrm{L}$ of calcein and $20 \mu \mathrm{L}$ of ethidium homodimer- 1

245 were added to $10 \mathrm{~mL}$ of DPBS. After treatment, media was removed, and the live-dead solution

246 was added to the wells. After incubating for $2 \mathrm{hrs}$ at room temperature in the dark, the solution

247 was removed and the cells were gently rinsed with DPBS three times, each time with 5 min

248 incubation. Stained cells were then imaged on a confocal microscope and quantified (Moghadam

249 et al., 2018).

250

251 Immunofluorescence (IF) in 3D Culture

252 IF was used to confirm apoptosis and autophagy findings by evaluating cleaved-PARP,

253 LC3, and p62 levels. C2C12 and RH30 cells were treated with DMSO or $10 \mu \mathrm{M}$ Simva for 96 or

25448 hrs, respectively. At the appropriate time point, media was removed, and cells were fixed by

255 incubating them with $4 \%$ paraformaldehyde in $\mathrm{PBS}$ for $15 \mathrm{~min}$ at room temperature.

256 Paraformaldehyde was then removed, and cells were washed 3 times with PBS. Cells were

257 blocked with blocking buffer (5\% goat serum, $0.3 \%$ Triton-X in RBS) at room temperature.

258 After 60 to 120 min, blocking buffer was removed and the appropriate primary antibody-p62,

259 LC3, or c-PARP - was diluted 1:300 in Antibody Buffer (1\% BSA, 0.3\% Triton-X in PBS) and 
260 incubated with the samples overnight at $4{ }^{\circ} \mathrm{C}$. The next day, the antibody solution was removed,

261 and cells were washed three times with PBS. Cells were then incubated with the appropriate

262 fluoro-conjugated secondary antibody which was diluted 1:400 in Antibody Buffer. Samples

263 were incubated in the dark for $2 \mathrm{hrs}$ at room temperature, and then washed with PBS. Finally, the

264 cells were incubated with DAPI solution for $1 \mathrm{hr}$ in the dark. After washing three times with

265 PBS, cells were immediately taken for imaging (Moghadam et al., 2018).

266

267 Statistical Analysis

268 All results were presented as mean $\pm \mathrm{SD}$, and the differences between the groups were 269 tested by one-way ANOVA or two-way ANOVA analysis (non-parametric, Brown-Forsythe 270 test), using GraphPad Prism 7.0. The confidence interval in each analysis was 95\%, and $p<0.05$ 271 was considered statistically significant.

272

273

274

275

276

277

$278 \quad$ RESULTS

279 Mevalonate Cascade Inhibition Induces Cell Death in Both RH3O and C2C12 Cells

280 We previously showed that the MA cascade inhibitor simvastatin induces cell death in a 281 broad range of primary cells (primary airway mesenchymal cells, and primary atrial fibroblasts)

282 (Ghavami et al., 2010b; Ghavami et al., 2011; Ghavami et al., 2014) and tumor cell lines 
283 (Alizadeh et al., 2018b; Alizadeh et al., 2017; Sheikholeslami et al., 2019) including breast 284 (MCF-7, MDA-MB231), brain (U87, U251), and lung (A549, H1965), as well as 285 medulloblastoma brain tumor cell lines (Daoy, D283, and D341 cells). Lovastatin and 286 mevalonate cascade inhibitors (GGTi-298, 6-Fluoromevalonate) also inhibit ovarian cancer 287 tumor growth (Kobayashi et al., 2017; Kobayashi et al., 2015).

288 We now demonstrate that simvastatin induces dose- $(0-20 \mu \mathrm{M})$ and time- $(0-96 \mathrm{hr})$ 289 dependent cell death in both RH30 (Fig. 1 A-D) and C2C12 cells (Fig. 1 E-H). In RH30 cells, 290 simvastatin $(20 \mu \mathrm{M})$ significantly induced cell death $(\mathrm{p}<0.05)$ in 24 hrs (Fig. 1 A), simvastatin $291(10,20 \mu \mathrm{M})$ significantly induced cell death $(\mathrm{p}<0.0001)$ in $48 \mathrm{hrs}$ (Fig. 1 B), simvastatin $(5,10$, $29220 \mu \mathrm{M})$ significantly induced cell death ( $<<0.05$, $\mathrm{p}<0.0001)$ in 72 and 96 hrs (Fig. 1 C\&D).

293 Interestingly, simvastatin $(0.5-20 \mu \mathrm{M})$ induced significant cell death $(\mathrm{p}<0.001, \mathrm{p}<0.0001)$ in all 294 time points (24-96 hr) in C2C12 cells (Fig.1 E-H). The morphology of RH30 cells treated with 295 simvastatin $(10 \mu \mathrm{M})$ is shown in Fig. $1 \mathrm{~J}$ and compared with RH30 time-matched control. 296 Simvastatin at concentrations of $\geq 2.5 \mu \mathrm{M}$ induced significant cell death in $\mathrm{C} 2 \mathrm{C} 12$ cells as 297 compared to RH30 cells ( $\mathrm{p}<0.01)$. RH30 Cells.

We know that mevaloante (MEV) can reverse statin-induced cell death in many cell 302 models, and GGPP is the major regulator of prenylation events among the isoprenoid 303 intermediates. We now show that MA $(5 \mathrm{mM})$ significantly $(\mathrm{p}<0.0001)$ inhibits simvastatin$304(10 \mu \mathrm{M})$ induced cell death in both C2C12 (Fig. 2 A) and RH30 (Fig. 2E) cells. While GGPP (30 
$\mu \mathrm{M})$ significantly $(\mathrm{p}<0.0001)$ inhibited simvastatin-induced cell death in both $\mathrm{C} 2 \mathrm{C} 12$ (Fig. 2B) and RH30 (Fig 2F) cells, it was more effective in rescuing RH30 cells than C2C12 cells (Fig. 2J). We found that FPP $(30 \mu \mathrm{M})$ did not significantly inhibit simvastatin-induced cell death in C2C12 cells (Fig. 2C), but it did significantly ( $\mathrm{p}<0.01)$ inhibit simvastatin-induced cell death in RH30 cells (Fig. 2G). FPP was also more effective in rescuing RH30 cells against simvastatin310 induced cell death (Fig. 2K). Furthermore, cholesterol $(50 \mu \mathrm{M})$ did not significantly inhibit simvastatin-induced cell death in either C2C12 (Fig. 2D) or RH30 (Fig. 2I).

Mevalonate Cascade Inhibition Induces Apoptosis in Both C2C12 and RH30 Cells

Mevalonate cascade inhibition can induce apoptosis in many cell models (Alizadeh et al., 2018b; Alizadeh et al., 2017; Ghavami et al., 2010b; Ghavami et al., 2012b). In this study, we show that simvastatin induces dose- $(5,10 \mu \mathrm{M})$ and time-depended $(48,72 \mathrm{hr})$ apoptosis in both C2C12 (Fig. 3A-C) and RH30 (Fig. 3D-F) cells (p < 0.01, p $<0.0001$ ). We also show that simvastatin significantly induces greater apoptosis in RH30 cells as compared to C2C12 cells (Fig. 3G) $(\mathrm{p}<0.01)$. in both RH30 and C2C12 cells. We show that simvastatin $(10 \mu \mathrm{M})$ increases LC3 lipidation and 325 induced p62 accumulation in both RH30 and C2C12 cells (Fig. 4A). To further confirm our 326 results, using GFP-LC3 and lysotracker immunostaining, we show that simvastatin induced 
327 significant increase of LC3 puncta in both $\mathrm{C} 2 \mathrm{C} 12$ and RH30 (Fig. 4B-D) while in C2C12 cells

328 prevented acidification of lysosomes (Fig. 4B) (lack of lysotracker red activity in simvastatin-

329 treated cells). We further confirmed our results using the autophagy inhibitor Bafilomycin A1

330 (Baf-A1, $100 \mathrm{nM}$ for $1 \mathrm{hr}$ ) and show that adding Baf-A1 does not significantly increase the

331 number of LC3 puncta in both $\mathrm{C} 2 \mathrm{C} 12$ (Fig. $4 \mathrm{E} \& \mathrm{G}$ ) and RH30 cells (Fig 4 F\&H). We also

332 confirmed increased numbers of autophagosomes in both C2C12 (Fig. 4I) and RH30 cells (Fig

$3334 \mathrm{~J})$. We then used Baf-A1 $(4 \mathrm{nM})$ in presence and absence of simvastatin $(10 \mu \mathrm{M}, 24 \mathrm{hrs})$ in

$334 \mathrm{C} 2 \mathrm{C} 12$ and $\mathrm{RH} 30$ cells (Fig 4K). Immunoblotting results confirmed further inhibition of

335 autophagy flux in both $\mathrm{C} 2 \mathrm{C} 12$ and RH30 cells (increase of LC3 $\beta$ lipidation and decrease of p62

336 degradation) (Fig 4K). Further, inhibition of autophagy significantly increased simvastatin-

337 induced myotoxicity in both $\mathrm{C} 2 \mathrm{C} 12$ and RH30 cells (Fig 4L\&M).

Simvastatin Induces Apoptotic Cell Death and Inhibits Autophagy in Both C2C12 and RH30

340 Cells in $3 D$ Culture

Cells cultured in 3D configurations using hydrogel biomaterials display a more

342 physiologically-relevant phenotype (Seyfoori et al., 2018). We recently showed that 3D-cultured

343 C2C12 and RH30 cells can be used to screen drugs (Moghadam et al., 2018). In this study, we

344 used this same 3D technique to evaluate the effect of simvastatin on C2C12 and RH30 cells. We

345 performed live/dead assays in 3D culture of C2C12 and RH30 cells and show that simvastatin (5,

$34610 \mu \mathrm{M})$ induces both dose- and time- (48, $96 \mathrm{hrs})$ dependent cell death (Fig. 5 A-H). Also,

347 simvastatin induced significant $(\mathrm{p}<0.0001)$ cell death in both C2C12 (Fig. 5 A, C, E\&F) and

348 RH30 (Fig. 5 B, D, G, H) cells in the 3D model. However, when cultured in the 3D hydrogel, 
349 simvastatin induced more cell death in RH30 cells as compared to $\mathrm{C} 2 \mathrm{C} 12$ cells. This was 350 opposite to the effect we observed when such cells were culture in standard 2D conditions. In 351 addition, simvastatin $(10 \mu \mathrm{M})$ induces apoptotic cell death in both $\mathrm{C} 2 \mathrm{C} 12$ and RH30 cells 352 (cleavage of PARP) in the 3D culture model (Fig. 5 I, J). We further investigated the effects of 353 simvastatin on autophagy in both $\mathrm{C} 2 \mathrm{C} 12$ and RH30 3D culture cells. We showed that 354 simvastatin inhibits autophagy flux in 3D culture model (increase of LC3 puncta and lack of 355 localization with p62) in both C2C12 and RH30 cells (Fig. 5 K\&L).

\section{DISCUSSION}

Our previous studies have demonstrated that the HMG-CoA reductase inhibitor simvastatin 364 induces endoplasmic reticulum stress/unfolded protein response, autophagy, and apoptosis in 365 human airway smooth muscle (HASM) cells, human airway fibroblasts (HAF), and human atrial 366 fibroblasts through inhibition of GGPP biosynthesis (Ghavami et al., 2012a; Ghavami et al., 367 2011; Ghavami et al., 2014). Previously, we also showed that simvastatin induces apoptotic cell 368 death in a wide variety of tumor cells (lung, brain, and breast) via inhibition of 369 geranylgeranylation of small Rho GTPases (Alizadeh et al., 2017). 
Statin-induced myotoxicity is a major concern for clinicians and basic scientists alike, and

371 several recent investigations have focused on the possible underlying mechanisms involved in

372 statin myotoxicity. In the current investigation, we used $\mathrm{C} 2 \mathrm{C} 12$ as our non-cancerous cell line

373 and RH30 as a cancer skeletal muscle cell line to elucidate the mechanisms underlying

374 simvastatin-induced myotoxicity. Our experiments utilized both monolayer 2D and 3D cell

375 culture models, which are more physiologically relevant accounting in part for the cellular 376 microenvironment.

377 Previous investigations have demonstrated that statin-induced myotoxicity occurs via 378 vacuolation of skeletal muscle fibers, blebbing of sarcolemma, and cell necrosis (Sakamoto et 379 al., 2007). Inhibition of the mitochondrial complex III is involved in statin-induced myotoxicity 380 in C2C12 cells (Schirris et al., 2015b). Other reports indicated that mitochondria (Bouitbir et al., 381 2012; Kwak et al., 2012; Schirris et al., 2015b), $\mathrm{Ca}^{2+}$ homeostasis (Sirvent et al., 2012), plasma 382 membrane mono-carboxylate transporter (Kobayashi et al., 2006), plasma membrane receptors 383 (Dricu et al., 1997; Siddals et al., 2004), and ubiquitin ligases (Cao et al., 2009) are statins' 384 primary targets for myotoxicity. Here we show that simvastatin induced cell death in both 385 C2C12 and RH30 cells. However, there were significant differences between C2C12 and RH30 386 in cell viability (MTT assay) after treatment with simvastatin in 2D monolayer cell culture 387 (simvastatin caused significantly greater reduction in $\mathrm{C} 2 \mathrm{C} 12$ cell viability as compared to 388 RH30). Since the MTT assay is based on the measurement of mitochondrial reductase activity to 389 produce formazon, our results suggest that simvastatin-induced cell death may be dependent on 390 the decrease of reductase activity in $\mathrm{C} 2 \mathrm{C} 12$ cell lines. Of note, statin-induced myotoxicity 391 (Graham et al., 2004) is augmented with the combination of drugs that block metabolic pathways 392 and decrease mitochondrial reductase activity in cells, such as cytochrome P450 and UDP- 
393 glucuronyltransferase 1A1 and 1A3 systems (Prueksaritanont et al., 2002). Consistent with 394 previous studies, our results demonstrate that simvastatin has greater myotoxicity in C2C12 395 (non-cancerous muscle) cells than RH30 (skeletal muscle cancer) cells.

We also show that simvastatin induced apoptosis in a time- and dose-dependent manner in 397 both C2C12 and RH30 cells. Interestingly, RH30 was more susceptible to apoptosis than C2C12 398 in 2D monolayer culture model (Figure 3). The rate of simvastatin-induced apoptosis in RH30 399 cells was $\sim 2$-fold greater than the $\mathrm{C} 2 \mathrm{C} 12$ cell line. Therefore, while simvastatin caused a 400 reduction in cell viability in $\mathrm{C} 2 \mathrm{C} 12$ cells, these cells were also less susceptible to apoptosis than 401 RH30 cells. This is not unexpected given that in the broader statin-cancer literature, cancer cells 402 are predominantly more sensitive to statin-induced cell death than their normal or non-cancerous 403 controls. These results intriguingly show that simvastatin-induced apoptosis in skeletal muscle 404 cells does not correlate with loss of cell viability as measured by the MTT assay; this suggests an 405 effect mediated via other mitochondrial factors. For example, in our previous investigations we 406 showed that simvastatin-induced apoptosis is dependent on the release of Smac/Diablo and 407 Omi/Htr2 from mitochondria in HASM cells and HAF (Ghavami et al., 2010b) and is 408 independent of the release of cytochrome $\mathrm{c}$ from mitochondria.

The role of cholesterol biosynthesis in statin-induced cell death has been widely 410 investigated and those results are consistent with ours (Graham et al., 2004; Sakamoto et al., 411 2007; Schirris et al., 2015b). Previous studies showed that statins reduce GGPP levels and 412 production of ubiquinones which are used as electron carriers in the electron transport chain 413 (Harper and Jacobson, 2007; Thompson et al., 2003). Consequently, the decrease of ubiquinone 414 production in cells leads to dysfunction of the electron transport chain, which reduces muscle 415 cell ATP levels, elevates free radical production, and induces apoptosis (Harper and Jacobson, 
416 2007; Thompson et al., 2003). Further, the impaired geranylgeranylation of proteins may be a

417 root cause in statin-associated myopathy (Cao et al., 2009; Johnson et al., 2004; Mullen et al.,

418 2010), a concept contested by work carried out in rhabdomyosarcoma rather than normal skeletal

419 muscle cells (Gee et al., 2015). Therefore, we decided to investigate the MA pathway in both

420 C2C12 and RMS cells. In our study, co-treatment with MA or GGPP inhibited simvastatin-

421 induced cell death in the $\mathrm{C} 2 \mathrm{C} 12$ cell line while co-treatment with cholesterol and FPP did not.

422 Takeda et al. demonstrated that the reduction of smooth muscle cell proliferation by simvastatin

423 was inhibited by GGPP, but not by FPP (Takeda et al., 2006). Their findings are compatible with

424 our results which show simvastatin signaling is dependent on GGPP in C2C12 cells. Our present

425 study also shows that in RH30 cells simvastatin-induced cell death is inhibited by MA and

426 GGPP, but not cholesterol (Fig 2). Unlike in C2C12 cells, we show that in RH30 cells

427 simvastatin-induced cell death was inhibited by FFP (Fig 2). These findings confirm that the

428 effect of simvastatin on cell death in both cells was mediated via inhibition of the MA pathway,

429 in particular, GGPP. In addition, we discovered that FPP may play an important role in

430 simvastatin-induced death mechanisms in RH30 cells.

GGPP and FPP are necessary for the prenylation of small Rho GTPase proteins including

432 Rho, Rac, Cdc42, Rab and Rac (Alizadeh et al., 2018b; Alizadeh et al., 2017; Ghavami et al.,

433 2010b; Ghavami et al., 2012a; Yeganeh et al., 2014). We show that simvastatin-induced cell

434 death is dependent on GGPP in $\mathrm{C} 2 \mathrm{C} 12$ cells. This indicates that Rho, Cdc42, and Rac GTPases

435 may be involved in cell death induction mechanisms in C2C12 cells. Conversely, in RH30 cells

436 both FPP and GGPP mediate simvastatin-induced cell death, suggesting that Ras GTPases may

437 also be involved via farnesylation pathways. 
439 simvastatin either induce or inhibit autophagy in different cell models (Ghavami et al., 2014;

440 Hwang et al., 2015; Vilimanovich et al., 2015; Whitehead, 2016). There are two recent articles

441 that showed hydrophobic statins induced autophagy in A204 RMS cells (Araki and Motojima,

442 2008; Gee et al., 2015). But, the exact molecular mechanisms of the autophagy flux, 443 autophagosome fusion and degradation steps of autophagy have not been investigated in RMS

444 cells. Many studies demonstrated that the LC3-II/LC3-I ratio is often used to determine the 445 activation of autophagy (Mizushima et al., 2010). The present results show that simvastatin 446 increased the conversion of light chain 3 (LC3)-I to LC3-phosphatidylethanolamine conjugate 447 (LC3-II) in both $\mathrm{C} 2 \mathrm{C} 12$ and $\mathrm{RH} 30$ cells by increasing the number of LC3 puncta 448 (immunofluorescence) and autophagosome formation (Figure 4). The protein p62 facilitates the 449 degradation of ubiquitinated protein aggregates by autophagy (Guo et al., 2013) and is a selective 450 substrate for autophagy and directly interacts with LC3 to mediate the degradation of 451 ubiquitinated protein aggregates by autophagy (Pankiv et al., 2007). Our results show that 452 simvastatin increases p62 accumulation in both $\mathrm{RH} 30$ and $\mathrm{C} 2 \mathrm{C} 12$ cell lines, therefore, 453 simvastatin inhibits autophagy flux in both cells lines. Moreover, our results showed that 454 simvastatin induced acidification of lysosomes in RH30 cells, but in C2C12 cells simvastatin 455 inhibited acidification of lysosomes (Fig. 4B). Taken together, our data demonstrates that 456 simvastatin inhibits autophagy flux in a time-dependent manner in both non-cancer C2C12 and 457 RMS RH30 cells. Therefore, we conclude that simvastatin inhibits autophagy flux in both 458 C2C12 and RH30. In RH30 cells, autophagy inhibitory activity occurs via inhibition of 459 lysosomal acidification, however, further investigation is required to prove this hypothesis. 460 Further blockage of autophagy flux increases the myotoxicity of simvastatin in both C2C12 and 
461 RH30 cells. These findings confirm the importance of autophagy flux inhibition in the 462 myotoxicity of statins. These results are inconsistent with our findings in HAF and HASM 463 (Ghavami et al., 2011; Ghavami et al., 2014). Also, Gu et al showed that simvastatin induces 464 autophagy in bronchial smooth muscle cells (BSMCs) and increases autophagy-related protein 465 Atg5, LC3B, and Beclin1 expression and autophagosome formation in lung tissue (Gu et al., 466 2017).

The effect of chemical compounds on cells have mostly been performed using 2D cell 468 culture models, where cell-cell interaction, extracellular matrix, and cellular morphology 469 significantly differ from their natural structure in tissues (Levinger et al., 2014). These 470 differences highly influence cellular growth and their response to different chemical compounds 471 (Levinger et al., 2014). Three-dimensional (3D) culture models have been introduced for drug 472 assessment to improve the relation between cell cultures and cellular microenvironment 473 (Friedrich et al., 2009). Recently, 3D culture models have been used as clinically relevant models 474 for the study of cell death and autophagy (Gomes et al., 2015; Ma et al., 2011). We examined the 475 effects of simvastatin in RH30 and C2C12 3D culture models (Fig. 5), which showed that 476 simvastatin induces significantly greater cell death in RH30 cells as compared to C2C12 cells. 477 Whereas, the cell death effects of simvastatin were greater in C2C12 cells as compared to RH30 478 cells in the 2D cell culture model. This shows how the cell microenvironment and 3D structure 479 can affect fundamental cellular response(s) including to chemical compounds or drugs. We also 480 observed that simvastatin inhibits autophagy flux in 3D culture of RH30 and C2C12 cells 481 (absence of localization of p62 and LC3 puncta) which correlates with our 2D observations. 482 Overall, our results indicate that 3D culture models are important tools for screening cytotoxic 
483 effects of chemical compounds as they can account for some of the effects of cellular matrix in 484 response to extracellular stress.

There are several limitations to this study that are important to mention. The dose of 486 simvastatin used in our experiments $(10 \mu \mathrm{M})$ is significantly higher than pharmacologic 487 concentrations found in human blood which is in the low nanogram/mL (nM) range (Ucar et al., 488 2000). However, we don't know if statins accumulate in human skeletal muscle, and whether 489 they reach micromolar concentrations. Furthermore, simvastatin's half-life is approximately 2 490 hours in plasma, and results can vary according to which statin is selected. In addition, normal 491 human skeletal muscle behaves differently than rhabdomyosarcoma cell line, so the effects 492 observed could manifest differently in human normal skeletal muscle.

In conclusion, we found that simvastatin induces cell death in both RH30 and C2C12 cells 494 in both 2D and 3D culture. Our results showed that simvastatin significantly decreases cellular 495 viability in $\mathrm{C} 2 \mathrm{C} 12$ cells compared to RH30 cells while it also significantly induces greater 496 apoptosis in RH30 cells compared to C2C12 cells. In addition, simvastatin inhibits autophagy 497 flux in both RH30 and C2C12 cells with differential effects on lysosomal acidification. We also 498 showed that simvastatin-induced cell death is dependent on both FPP and GGPP in RH30 cells 499 while it is only dependent on GGPP in C2C12 cells. Our current investigation provides solid 500 evidence that both autophagy and apoptosis are involved in statin-induced myotoxicity, and 501 further, autophagy flux inhibition varies between the non-cancerous and cancer muscle cell lines. 
505 Investigator operating grant, CancerCare Manitoba Operating Grant and NIMAD operating 506 grant. Shahla Shojaei was supported by HSC operating grant and Mitacs Accelerate postdoctoral 507 award. Simone C da Silva Rosa was supported by University of Manitoba Graduate Fellowship 508 (UMGF) PhD studentship. Joseph W Gordon was supported by NSERC Discovery grant. Ehsan 509 Samiei was supported by a Collaborative Research and Development Grant from NSERC and 510 BC Cancer Foundation. AZ was supported by UC Davis PI Bridge Fund. 
Figure 1: Simvastatin induces cell death in RH30 and C2C12 cells. (A-D). RH30 cells were treated with simvastatin $(0.5,1,2.5,5,10,20 \mu \mathrm{M})$ and cell viability was assessed $24,48,72$ and 96 hrs after that by MTT assay. Control cells for each time point were treated with the solvent control (DMSO). Results are expressed as a percentage of corresponding time point control and 517 represent the means $\pm \mathrm{SD}$ of 15 replicates in three independent experiments $(*, p<0.05 ; * * * *$, $518 p<0.0001) .(\mathrm{E}-\mathrm{H}) . \mathrm{C} 2 \mathrm{C} 12$ cells were treated with simvastatin $(0.5,1,2.5,5,10,20 \mu \mathrm{M})$ and cell 519 viability was assessed 24, 48, 72 and 96 hrs after that by MTT assay. Control cells for each time 520 point were treated with the solvent control (DMSO). Results are expressed as a percentage of 521 corresponding time point control and represent the means \pm SD of 15 replicates in three 522 independent experiments $(* * * *, p<0.0001)$. (I\&J). Simvastatin significantly decreased cell 523 viability in C2C12 compared to RH30 cells. $\mathrm{RH} 30$ and $\mathrm{C} 2 \mathrm{C} 12$ cells were treated with 524 simvastatin $(0.5,1,2.5,5,10,20 \mu \mathrm{M})$ and cell viability was assessed 24, 48, 72 and 96 hrs after 525 that by MTT assay. Control cells for each time point were treated with the solvent control 526 (DMSO). Results are expressed as a percentage of corresponding time point control and 527 represent the means $\pm \mathrm{SD}$ of 15 replicates in three independent experiments $(* * * *, p<0.0001)$. 528 (K\&L). Phase contrast microscopy showed that simvastatin $(10 \mu \mathrm{M}, 48$ hrs $)$ induces 529 morphological changes (cellular shrinkage) and decrease in the number of cells in RH30 cells. mevalonate cascade isoprenoid mediators. (A-H) $5 \mathrm{mM}$ MA, $30 \mu \mathrm{M}$ GGPP, $30 \mu \mathrm{M}$ FPP, or $53350 \mu \mathrm{M}$ cholesterol, were added to the cells $4 \mathrm{hrs}$ prior to treatment with simvastatin $(10 \mu \mathrm{M}, 96$ 
534 hrs). Cell death was measured by MTT assay in C2C12 (A-D), and RH30 cells. For each 535 experiment control cells were treated with simvastatin solvent (DMSO) alone (control) or with 536 both DMSO and the appropriate solvent (i.e. ethanol for "mevalonate control). Mevalonate (A, 537 E) and GGPP (B, F) significantly inhibited simvastatin induced cell death in both $\mathrm{C} 2 \mathrm{C} 12$ and 538 RH30 cells while FPP (C, G) only inhibited simvastatin-induced cell death in RH30 cells. Our 539 results also showed that cholesterol $(\mathrm{D}, \mathrm{H})$ is not involved in simvastatin induced cell death in $540 \mathrm{C} 2 \mathrm{C} 12$ and $\mathrm{RH} 30$ cells. Results are expressed as mean \pm SD of 15 replicate in 3 independent 541 experiments $(* \mathrm{p}<0.05, * * * \mathrm{p}<0.001$, and $* * * * \mathrm{p}<0.0001)$. (I\&J) Our results also showed that 542 FPP (I) and GGPP (J) significantly rescues simvastatin induced cell death in RH30 cells 543 compared to $\mathrm{C} 2 \mathrm{C} 12$ cells.

RH30 cells. Percent sub-G1 (A-C) C2C12, (D-F) RH30, abundance induced by simvastatin (5, 547 and $10 \mu \mathrm{M}$ ) or DMSO solvent control after 48 and 72 hrs. Results represent the means \pm SD of 9 548 replicates in three independent experiments. $* * * * \mathrm{p}<0.0001$; and $* * * \mathrm{p}<0.001$ compared to time549 matched control. Representative figures of the flow cytometry histogram for C2C12 and RH30 550 are shown (A and D). Our results showed that simvastatin $(10 \mu \mathrm{M})$ induced significant more 551 apoptosis in RH30 compared to C2C12 cells in $48(\mathrm{G})$ and $72(\mathrm{H})$ hours $(* * \mathrm{p}<0.01$, and **** $\mathrm{p}$ $552<0.0001)$ 
556 collected. Immunoblotting for LC3 $\beta$ and p62 were performed. The results showed that 557 simvastatin induced accumulation of LC $3 \beta$ II and inhibits p62 degradation in both C2C12 and 558 RH30 cells. C2C12 and C2C12 cells were treated with simvastatin $(10 \mu \mathrm{M}, 24 \mathrm{~h})$. (B-D) using 559 immunocytochemistry LC3 puncta and changes in lysosomal activity (LysoTracker red staining) 560 has been investigated. The results showed that simvastatin increased LC3 puncta in both cell 561 lines. Our results also showed that simvastatin $(10 \mu \mathrm{M}, 24$ hours $)$ increase lysosomal acidity in 562 RH30 while inhibits lysosomal acidification in C2C12 cells (B). C2C12 (E) and RH30 (F) cells 563 were treated with simvastatin $(10 \mu \mathrm{M}, 24 \mathrm{~h})$ and Baf-A1 (100 nM, +3 hours) followed by 564 immunocytochemistry to evaluate LC3 puncta and changes in lysosomal activity (LysoTracker 565 red staining). The results showed that simvastatin increased LC3 puncta and decreased 566 LysoTracker red fluorescence intensity in C2C12 cells while increased LC3 puncta and increased 567 LysoTracker red fluorescence intensity in RH30 cells. On the other hand, Baf-A1 and 568 simvastatin + Baf-A1 did not significantly change LC 3 puncta in both $\mathrm{C} 2 \mathrm{C} 12$ and RH 30 cells $(\mathrm{G}$, 569 H) showing that simvastatin inhibited autophagy flux like Baf-A1. Transmission electron 570 microscopy showed that in treated $\mathrm{C} 2 \mathrm{C} 12$ (I) and RH30 (J) cells there are accumulated 571 autophagosome-like structures compared to control and normal cells after 72 hours treatment. 572 Arrows show the autophagolysosomes containing the cargo (magnification $\times 11,600$ ). Autophagy 573 inhibition (Baf-A1, $4 \mathrm{nM}, 24$ hours) significantly increased simvastatin-induced cell death (10 $574 \mu \mathrm{M}, 24$ hours) in RH30 (L) and $\mathrm{C} 2 \mathrm{C} 12$ (M) cell lines (** $\mathrm{p}<0.01$, Results represent the 575 means \pm SD of 15 replicates in three independent experiments). Baf-A1 (4 nM) and simvastatin $576(10 \mu \mathrm{M})$ combination did not increase accumulation of LC3ß-II and p62 in both RH30 and 577 C2C12 cells (K). 
579 Figure 5: Simvastatin induces apoptosis and autophagy in C2C12 and RH30 3D culture.

580 (A\&B). Bright field image of C2C12 (A) and RH30 (B) 3D culture which shows the morphology 581 of untreated and simvastatin treated cells $(5,10 \mu \mathrm{M}, 96$ hours $)$ in 3D culture. (C-H). Viability 582 assay was done by adding the live/dead solution to cells 48 and 96 hours after treatment with 583 simvastatin $(0-20 \mu \mathrm{M})$. Cells were incubated for 2 hours in the dark at room temperature, rinsed 584 three times with DPBS, and confocal microscopy was used to capture live/dead cell images in 585 C2C12 (C) and RH30 (D) cells. Quantification of live/dead assay was measured by calculating 586 the ratio of live: total cells which showed a significant decrease in viability of C2C12 (E\&F) and 587 RH30 $(\mathrm{G} \& \mathrm{H})$ cells treated with different concentrations of simvastatin. The data showed 588 simvastatin significantly induces cell death in both $\mathrm{C} 2 \mathrm{C} 12$ and RH30 cells $(P<0.0001)$ while 589 simvastatin induces more cell death in RH30 compared to C2C12 cells. (I\&J) IF labeling of 590 C2C12 cells (I) and RH30 cells (J) by cleaved PARP following treatment with simvastatin $591(10 \mu \mathrm{M}, 48$ hours $)$ increased number of cells with cleaved PARP in simvastatin treated cells in 592 comparison to control cells which is the hallmark of increase of apoptosis in these cells. (K\&L) 593 After treatment of C2C12 (K) and RH30 (L) cells with simvastatin $(10 \mu \mathrm{M}, 48 \mathrm{~h})$, cells were IF 594 labeled with autophagosome markers, LC3 and P62. Data showed that simvastatin increases LC3 595 puncta (green) which is not localized with p62 compared to corresponding time-matched control, 596 a hallmark of autophagy flux inhibition in C2C12 and RH30 3D culture 


\section{REFERENCES:}

603 Alizadeh, J., Glogowska, A., Thliveris, J., Kalantari, F., Shojaei, S., Hombach-Klonisch, S., 604 Klonisch, T., Ghavami, S., 2018a. Autophagy modulates transforming growth factor beta 1 605 induced epithelial to mesenchymal transition in non-small cell lung cancer cells. Biochim 606 Biophys Acta Mol Cell Res 1865, 749-768.

607 Alizadeh, J., Shojaei, S., da Silva Rosa, S., Rezaei Moghadam, A., Zeki, A.A., Hashemi, M., 608 Los, M.J., Gordon, J.W., Ghavami, S., 2018b. Detection of Small GTPase Prenylation and GTP 609 Binding Using Membrane Fractionation and GTPase-linked Immunosorbent Assay. Journal of 610 visualized experiments : JoVE.

611 Alizadeh, J., Zeki, A.A., Mirzaei, N., Tewary, S., Rezaei Moghadam, A., Glogowska, A., 612 Nagakannan, P., Eftekharpour, E., Wiechec, E., Gordon, J.W., Xu, F.Y., Field, J.T., Yoneda, 613 K.Y., Kenyon, N.J., Hashemi, M., Hatch, G.M., Hombach-Klonisch, S., Klonisch, T., Ghavami, 614 S., 2017. Mevalonate Cascade Inhibition by Simvastatin Induces the Intrinsic Apoptosis Pathway 615 via Depletion of Isoprenoids in Tumor Cells. Scientific reports 7, 44841.

616 Amiri, S., Dastghaib, S., Ahmadi, M., Mehrbod, P., Khadem, F., Behrooj, H., Aghanoori, M.R., 617 Machaj, F., Ghamsari, M., Rosik, J., Hudecki, A., Afkhami, A., Hashemi, M., Los, M.J., 618 Mokarram, P., Madrakian, T., Ghavami, S., 2019. Betulin and its derivatives as novel 619 compounds with different pharmacological effects. Biotechnol Adv.

620 Araki, M., Motojima, K., 2008. Hydrophobic statins induce autophagy in cultured human 621 rhabdomyosarcoma cells. Biochem Biophys Res Commun 367, 462-467. 
622 Baba, T.T., Nemoto, T.K., Miyazaki, T., Oida, S., 2008. Simvastatin suppresses the 623 differentiation of C2C12 myoblast cells via a Rac pathway. J Muscle Res Cell Motil 29, 127624134.

625 Ballantyne, C.M., Corsini, A., Davidson, M.H., Holdaas, H., Jacobson, T.A., Leitersdorf, E., 626 Marz, W., Reckless, J.P., Stein, E.A., 2003. Risk for myopathy with statin therapy in high-risk 627 patients. Arch Intern Med 163, 553-564.

628 Bhardwaj, S., Selvarajah, S., Schneider, E.B., 2013. Muscular effects of statins in the elderly 629 female: a review. Clin Interv Aging 8, 47-59.

630 Bouitbir, J., Charles, A.L., Echaniz-Laguna, A., Kindo, M., Daussin, F., Auwerx, J., Piquard, F., 631 Geny, B., Zoll, J., 2012. Opposite effects of statins on mitochondria of cardiac and skeletal 632 muscles: a 'mitohormesis' mechanism involving reactive oxygen species and PGC-1. European 633 heart journal 33, 1397-1407.

634 Cao, P., Hanai, J., Tanksale, P., Imamura, S., Sukhatme, V.P., Lecker, S.H., 2009. Statin-induced 635 muscle damage and atrogin-1 induction is the result of a geranylgeranylation defect. FASEB 636 journal : official publication of the Federation of American Societies for Experimental Biology $637 \quad 23,2844-2854$.

638 Cartocci, V., Servadio, M., Trezza, V., Pallottini, V., 2017. Can Cholesterol Metabolism 639 Modulation Affect Brain Function and Behavior? J Cell Physiol 232, 281-286.

640 Crick, D.C., Andres, D.A., Waechter, C.J., 1997. Novel salvage pathway utilizing farnesol and 641 geranylgeraniol for protein isoprenylation. Biochem Biophys Res Commun 237, 483-487.

642 Dricu, A., Wang, M., Hjertman, M., Malec, M., Blegen, H., Wejde, J., Carlberg, M., Larsson, O., 643 1997. Mevalonate-regulated mechanisms in cell growth control: role of dolichyl phosphate in 
644 expression of the insulin-like growth factor-1 receptor (IGF-1R) in comparison to Ras 645 prenylation and expression of c-myc. Glycobiology 7, 625-633.

646 Endo, A., Tsujita, Y., Kuroda, M., Tanzawa, K., 1977. Inhibition of cholesterol synthesis in vitro 647 and in vivo by ML-236A and ML-236B, competitive inhibitors of 3-hydroxy-3-methylglutaryl648 coenzyme A reductase. Eur J Biochem 77, 31-36.

649 Field, J.T., Martens, M.D., Mughal, W., Hai, Y., Chapman, D., Hatch, G.M., Ivanco, T.L., Diehl650 Jones, W., Gordon, J.W., 2018. Misoprostol regulates Bnip3 repression and alternative splicing 651 to control cellular calcium homeostasis during hypoxic stress. Cell Death Discov 4, 37.

652 Friedrich, J., Seidel, C., Ebner, R., Kunz-Schughart, L.A., 2009. Spheroid-based drug screen: 653 considerations and practical approach. Nature protocols 4, 309-324.

654 Gee, R.H., Spinks, J.N., Malia, J.M., Johnston, J.D., Plant, N.J., Plant, K.E., 2015. Inhibition of 655 prenyltransferase activity by statins in both liver and muscle cell lines is not causative of 656 cytotoxicity. Toxicology 329, 40-48.

657 Ghavami, S., Eshragi, M., Ande, S.R., Chazin, W.J., Klonisch, T., Halayko, A.J., McNeill, K.D., 658 Hashemi, M., Kerkhoff, C., Los, M., 2010a. S100A8/A9 induces autophagy and apoptosis via 659 ROS-mediated cross-talk between mitochondria and lysosomes that involves BNIP3. Cell Res $660 \quad 20,314-331$.

661 Ghavami, S., Kerkhoff, C., Los, M., Hashemi, M., Sorg, C., Karami-Tehrani, F., 2004. 662 Mechanism of apoptosis induced by S100A8/A9 in colon cancer cell lines: the role of ROS and 663 the effect of metal ions. J Leukoc Biol 76, 169-175.

664 Ghavami, S., Mutawe, M.M., Hauff, K., Stelmack, G.L., Schaafsma, D., Sharma, P., McNeill, 665 K.D., Hynes, T.S., Kung, S.K., Unruh, H., Klonisch, T., Hatch, G.M., Los, M., Halayko, A.J., 666 2010b. Statin-triggered cell death in primary human lung mesenchymal cells involves p53- 
667 PUMA and release of Smac and Omi but not cytochrome c. Biochimica et biophysica acta 1803, $668 \quad 452-467$.

669 Ghavami, S., Mutawe, M.M., Schaafsma, D., Yeganeh, B., Unruh, H., Klonisch, T., Halayko, 670 A.J., 2012a. Geranylgeranyl transferase 1 modulates autophagy and apoptosis in human airway 671 smooth muscle. American journal of physiology. Lung cellular and molecular physiology 302, 672 L420-428.

673 Ghavami, S., Mutawe, M.M., Sharma, P., Yeganeh, B., McNeill, K.D., Klonisch, T., Unruh, H., 674 Kashani, H.H., Schaafsma, D., Los, M., Halayko, A.J., 2011. Mevalonate cascade regulation of 675 airway mesenchymal cell autophagy and apoptosis: a dual role for p53. PloS one 6, e16523.

676 Ghavami, S., Sharma, P., Yeganeh, B., Ojo, O.O., Jha, A., Mutawe, M.M., Kashani, H.H., Los, 677 M.J., Klonisch, T., Unruh, H., Halayko, A.J., 2014. Airway mesenchymal cell death by 678 mevalonate cascade inhibition: integration of autophagy, unfolded protein response and 679 apoptosis focusing on Bcl2 family proteins. Biochimica et biophysica acta 1843, 1259-1271.

680 Ghavami, S., Yeganeh, B., Stelmack, G.L., Kashani, H.H., Sharma, P., Cunnington, R., Rattan, 681 S., Bathe, K., Klonisch, T., Dixon, I.M., Freed, D.H., Halayko, A.J., 2012b. Apoptosis, 682 autophagy and ER stress in mevalonate cascade inhibition-induced cell death of human atrial 683 fibroblasts. Cell Death Dis 3, e330.

684 Gomes, L.R., Vessoni, A.T., Menck, C.F., 2015. Three-dimensional microenvironment confers 685 enhanced sensitivity to doxorubicin by reducing p53-dependent induction of autophagy. 686 Oncogene 34, 5329-5340.

687 Graham, D.J., Staffa, J.A., Shatin, D., Andrade, S.E., Schech, S.D., La Grenade, L., Gurwitz, 688 J.H., Chan, K.A., Goodman, M.J., Platt, R., 2004. Incidence of hospitalized rhabdomyolysis in 689 patients treated with lipid-lowering drugs. Jama 292, 2585-2590. 
690 Grundy, S.M., Vega, G.L., 1985. Influence of mevinolin on metabolism of low density 691 lipoproteins in primary moderate hypercholesterolemia. J Lipid Res 26, 1464-1475.

692 Gu, W., Cui, R., Ding, T., Li, X., Peng, J., Xu, W., Han, F., Guo, X., 2017. Simvastatin alleviates 693 airway inflammation and remodelling through up-regulation of autophagy in mouse models of 694 asthma. Respirology (Carlton, Vic.) 22, 533-541.

695 Guo, X., Dong, Y., Yin, S., Zhao, C., Huo, Y., Fan, L., Hu, H., 2013. Patulin induces pro696 survival functions via autophagy inhibition and p62 accumulation. Cell Death Dis 4, e822.

697 Harper, C.R., Jacobson, T.A., 2007. The broad spectrum of statin myopathy: from myalgia to 698 rhabdomyolysis. Current opinion in lipidology 18, 401-408.

699 Hashemi, M., Ghavami, S., Eshraghi, M., Booy, E.P., Los, M., 2007. Cytotoxic effects of intra 700 and extracellular zinc chelation on human breast cancer cells. Eur J Pharmacol 557, 9-19.

701 Hashemi, M., Hoshyar, R., Ande, S.R., Chen, Q.M., Solomon, C., Zuse, A., Naderi, M., 2017. 702 Mevalonate Cascade and its Regulation in Cholesterol Metabolism in Different Tissues in Health 703 and Disease. Curr Mol Pharmacol 10, 13-26.

704 Hombach-Klonisch, S., Mehrpour, M., Shojaei, S., Harlos, C., Pitz, M., Hamai, A., 705 Siemianowicz, K., Likus, W., Wiechec, E., Toyota, B.D., Hoshyar, R., Seyfoori, A., Sepehri, Z., 706 Ande, S.R., Khadem, F., Akbari, M., Gorman, A.M., Samali, A., Klonisch, T., Ghavami, S., 707 2018. Glioblastoma and chemoresistance to alkylating agents: Involvement of apoptosis, 708 autophagy, and unfolded protein response. Pharmacol Ther 184, 13-41.

709 Hwang, K.E., Kim, Y.S., Jung, J.W., Kwon, S.J., Park, D.S., Cha, B.K., Oh, S.H., Yoon, K.H., 710 Jeong, E.T., Kim, H.R., 2015. Inhibition of autophagy potentiates pemetrexed and simvastatin711 induced apoptotic cell death in malignant mesothelioma and non-small cell lung cancer cells. 712 Oncotarget 6, 29482-29496. 
713 Illingworth, D.R., Sexton, G.J., 1984. Hypocholesterolemic effects of mevinolin in patients with 714 heterozygous familial hypercholesterolemia. J Clin Invest 74, 1972-1978.

715 Jaskiewicz, A., Pajak, B., Labieniec-Watala, M., Palma, C., Orzechowski, A., 2019. Diverse 716 Action of Selected Statins on Skeletal Muscle Cells-An Attempt to Explain the Protective Effect 717 of Geranylgeraniol (GGOH) in Statin-Associated Myopathy (SAM). J Clin Med 8.

718 Jiao, X., Ashtari, N., Rahimi-Balaei, M., Chen, Q.M., Badbezanchi, I., Shojaei, S., Marzban, A., 719 Mirzaei, N., Chung, S., Guan, T., Li, J., Vriend, J., Mehr, S.E., Kong, J., Marzban, H., 2017. 720 Mevalonate Cascade and Neurodevelopmental and Neurodegenerative Diseases: Future Targets 721 for Therapeutic Application. Curr Mol Pharmacol 10, 115-140.

722 Johnson, T.E., Zhang, X., Bleicher, K.B., Dysart, G., Loughlin, A.F., Schaefer, W.H., 723 Umbenhauer, D.R., 2004. Statins induce apoptosis in rat and human myotube cultures by 724 inhibiting protein geranylgeranylation but not ubiquinone. Toxicology and applied pharmacology 725 200, 237-250.

726 Klionsky, D.J., Abdelmohsen, K., Abe, A., Abedin, M.J., Abeliovich, H., Acevedo Arozena, A., 727 Adachi, H., Adams, C.M., Adams, P.D., Adeli, K., Adhihetty, P.J., Adler, S.G., Agam, G., 728 Agarwal, R., Aghi, M.K., Agnello, M., Agostinis, P., Aguilar, P.V., Aguirre-Ghiso, J., Airoldi, 729 E.M., Ait-Si-Ali, S., Akematsu, T., Akporiaye, E.T., Al-Rubeai, M., Albaiceta, G.M., Albanese, 730 C., Albani, D., Albert, M.L., Aldudo, J., Algul, H., Alirezaei, M., Alloza, I., Almasan, A., 731 Almonte-Beceril, M., Alnemri, E.S., Alonso, C., Altan-Bonnet, N., Altieri, D.C., Alvarez, S., 732 Alvarez-Erviti, L., Alves, S., Amadoro, G., Amano, A., Amantini, C., Ambrosio, S., Amelio, I., 733 Amer, A.O., Amessou, M., Amon, A., An, Z., Anania, F.A., Andersen, S.U., Andley, U.P., 734 Andreadi, C.K., Andrieu-Abadie, N., Anel, A., Ann, D.K., Anoopkumar-Dukie, S., Antonioli, 735 M., Aoki, H., Apostolova, N., Aquila, S., Aquilano, K., Araki, K., Arama, E., Aranda, A., Araya, 
J., Arcaro, A., Arias, E., Arimoto, H., Ariosa, A.R., Armstrong, J.L., Arnould, T., Arsov, I., Asanuma, K., Askanas, V., Asselin, E., Atarashi, R., Atherton, S.S., Atkin, J.D., Attardi, L.D., Auberger, P., Auburger, G., Aurelian, L., Autelli, R., Avagliano, L., Avantaggiati, M.L., Avrahami, L., Awale, S., Azad, N., Bachetti, T., Backer, J.M., Bae, D.H., Bae, J.S., Bae, O.N., Bae, S.H., Baehrecke, E.H., Baek, S.H., Baghdiguian, S., Bagniewska-Zadworna, A., Bai, H., Bai, J., Bai, X.Y., Bailly, Y., Balaji, K.N., Balduini, W., Ballabio, A., Balzan, R., Banerjee, R., Banhegyi, G., Bao, H., Barbeau, B., Barrachina, M.D., Barreiro, E., Bartel, B., Bartolome, A., Bassham, D.C., Bassi, M.T., Bast, R.C., Jr., Basu, A., Batista, M.T., Batoko, H., Battino, M., Bauckman, K., Baumgarner, B.L., Bayer, K.U., Beale, R., Beaulieu, J.F., Beck, G.R., Jr., Becker, C., Beckham, J.D., Bedard, P.A., Bednarski, P.J., Begley, T.J., Behl, C., Behrends, C., Behrens, G.M., Behrns, K.E., Bejarano, E., Belaid, A., Belleudi, F., Benard, G., Berchem, G., Bergamaschi, D., Bergami, M., Berkhout, B., Berliocchi, L., Bernard, A., Bernard, M., Bernassola, F., Bertolotti, A., Bess, A.S., Besteiro, S., Bettuzzi, S., Bhalla, S., Bhattacharyya, S., Bhutia, S.K., Biagosch, C., Bianchi, M.W., Biard-Piechaczyk, M., Billes, V., Bincoletto, C., Bingol, B., Bird, S.W., Bitoun, M., Bjedov, I., Blackstone, C., Blanc, L., Blanco, G.A., Blomhoff, H.K., Boada-Romero, E., Bockler, S., Boes, M., Boesze-Battaglia, K., Boise, L.H., Bolino, A., Boman, A., Bonaldo, P., Bordi, M., Bosch, J., Botana, L.M., Botti, J., Bou, G., Bouche, M., Bouchecareilh, M., Boucher, M.J., Boulton, M.E., Bouret, S.G., Boya, P., BoyerGuittaut, M., Bozhkov, P.V., Brady, N., Braga, V.M., Brancolini, C., Braus, G.H., Bravo-San Pedro, J.M., Brennan, L.A., Bresnick, E.H., Brest, P., Bridges, D., Bringer, M.A., Brini, M., Brito, G.C., Brodin, B., Brookes, P.S., Brown, E.J., Brown, K., Broxmeyer, H.E., Bruhat, A., Brum, P.C., Brumell, J.H., Brunetti-Pierri, N., Bryson-Richardson, R.J., Buch, S., Buchan, A.M., Budak, H., Bulavin, D.V., Bultman, S.J., Bultynck, G., Bumbasirevic, V., Burelle, Y., Burke, 
R.E., Burmeister, M., Butikofer, P., Caberlotto, L., Cadwell, K., Cahova, M., Cai, D., Cai, J.,

Cai, Q., Calatayud, S., Camougrand, N., Campanella, M., Campbell, G.R., Campbell, M.,

Campello, S., Candau, R., Caniggia, I., Cantoni, L., Cao, L., Caplan, A.B., Caraglia, M.,

762 Cardinali, C., Cardoso, S.M., Carew, J.S., Carleton, L.A., Carlin, C.R., Carloni, S., Carlsson,

763

S.R., Carmona-Gutierrez, D., Carneiro, L.A., Carnevali, O., Carra, S., Carrier, A., Carroll, B.,

764 Casas, C., Casas, J., Cassinelli, G., Castets, P., Castro-Obregon, S., Cavallini, G., Ceccherini, I.,

765 Cecconi, F., Cederbaum, A.I., Cena, V., Cenci, S., Cerella, C., Cervia, D., Cetrullo, S.,

766 Chaachouay, H., Chae, H.J., Chagin, A.S., Chai, C.Y., Chakrabarti, G., Chamilos, G., Chan, 767 E.Y., Chan, M.T., Chandra, D., Chandra, P., Chang, C.P., Chang, R.C., Chang, T.Y., Chatham, 768 J.C., Chatterjee, S., Chauhan, S., Che, Y., Cheetham, M.E., Cheluvappa, R., Chen, C.J., Chen, 769 G., Chen, G.C., Chen, G., Chen, H., Chen, J.W., Chen, J.K., Chen, M., Chen, M., Chen, P., 770 Chen, Q., Chen, Q., Chen, S.D., Chen, S., Chen, S.S., Chen, W., Chen, W.J., Chen, W.Q., Chen, 771 W., Chen, X., Chen, Y.H., Chen, Y.G., Chen, Y., Chen, Y., Chen, Y., Chen, Y.J., Chen, Y.Q., 772 Chen, Y., Chen, Z., Chen, Z., Cheng, A., Cheng, C.H., Cheng, H., Cheong, H., Cherry, S., 773 Chesney, J., Cheung, C.H., Chevet, E., Chi, H.C., Chi, S.G., Chiacchiera, F., Chiang, H.L., 774 Chiarelli, R., Chiariello, M., Chieppa, M., Chin, L.S., Chiong, M., Chiu, G.N., Cho, D.H., Cho, 775 S.G., Cho, W.C., Cho, Y.Y., Cho, Y.S., Choi, A.M., Choi, E.J., Choi, E.K., Choi, J., Choi, M.E., 776 Choi, S.I., Chou, T.F., Chouaib, S., Choubey, D., Choubey, V., Chow, K.C., Chowdhury, K., 777 Chu, C.T., Chuang, T.H., Chun, T., Chung, H., Chung, T., Chung, Y.L., Chwae, Y.J., 778 Cianfanelli, V., Ciarcia, R., Ciechomska, I.A., Ciriolo, M.R., Cirone, M., Claerhout, S., Clague, 779 M.J., Claria, J., Clarke, P.G., Clarke, R., Clementi, E., Cleyrat, C., Cnop, M., Coccia, E.M., 780 Cocco, T., Codogno, P., Coers, J., Cohen, E.E., Colecchia, D., Coletto, L., Coll, N.S., Colucci781 Guyon, E., Comincini, S., Condello, M., Cook, K.L., Coombs, G.H., Cooper, C.D., Cooper, 
J.M., Coppens, I., Corasaniti, M.T., Corazzari, M., Corbalan, R., Corcelle-Termeau, E., Cordero, M.D., Corral-Ramos, C., Corti, O., Cossarizza, A., Costelli, P., Costes, S., Cotman, S.L., CotoMontes, A., Cottet, S., Couve, E., Covey, L.R., Cowart, L.A., Cox, J.S., Coxon, F.P., Coyne, C.B., Cragg, M.S., Craven, R.J., Crepaldi, T., Crespo, J.L., Criollo, A., Crippa, V., Cruz, M.T., Cuervo, A.M., Cuezva, J.M., Cui, T., Cutillas, P.R., Czaja, M.J., Czyzyk-Krzeska, M.F., Dagda, R.K., Dahmen, U., Dai, C., Dai, W., Dai, Y., Dalby, K.N., Dalla Valle, L., Dalmasso, G., D'Amelio, M., Damme, M., Darfeuille-Michaud, A., Dargemont, C., Darley-Usmar, V.M., Dasarathy, S., Dasgupta, B., Dash, S., Dass, C.R., Davey, H.M., Davids, L.M., Davila, D., Davis, R.J., Dawson, T.M., Dawson, V.L., Daza, P., de Belleroche, J., de Figueiredo, P., de Figueiredo, R.C., de la Fuente, J., De Martino, L., De Matteis, A., De Meyer, G.R., De Milito, A., De Santi, M., de Souza, W., De Tata, V., De Zio, D., Debnath, J., Dechant, R., Decuypere, J.P., Deegan, S., Dehay, B., Del Bello, B., Del Re, D.P., Delage-Mourroux, R., Delbridge, L.M., Deldicque, L., Delorme-Axford, E., Deng, Y., Dengjel, J., Denizot, M., Dent, P., Der, C.J., Deretic, V., Derrien, B., Deutsch, E., Devarenne, T.P., Devenish, R.J., Di Bartolomeo, S., Di Daniele, N., Di Domenico, F., Di Nardo, A., Di Paola, S., Di Pietro, A., Di Renzo, L., DiAntonio, A., DiazAraya, G., Diaz-Laviada, I., Diaz-Meco, M.T., Diaz-Nido, J., Dickey, C.A., Dickson, R.C., Diederich, M., Digard, P., Dikic, I., Dinesh-Kumar, S.P., Ding, C., Ding, W.X., Ding, Z., Dini, L., Distler, J.H., Diwan, A., Djavaheri-Mergny, M., Dmytruk, K., Dobson, R.C., Doetsch, V., Dokladny, K., Dokudovskaya, S., Donadelli, M., Dong, X.C., Dong, X., Dong, Z., Donohue, T.M., Jr., Doran, K.S., D'Orazi, G., Dorn, G.W., 2nd, Dosenko, V., Dridi, S., Drucker, L., Du, J., Du, L.L., Du, L., du Toit, A., Dua, P., Duan, L., Duann, P., Dubey, V.K., Duchen, M.R., Duchosal, M.A., Duez, H., Dugail, I., Dumit, V.I., Duncan, M.C., Dunlop, E.A., Dunn, W.A., Jr., Dupont, N., Dupuis, L., Duran, R.V., Durcan, T.M., Duvezin-Caubet, S., Duvvuri, U., Eapen, V., 
Ebrahimi-Fakhari, D., Echard, A., Eckhart, L., Edelstein, C.L., Edinger, A.L., Eichinger, L., Eisenberg, T., Eisenberg-Lerner, A., Eissa, N.T., El-Deiry, W.S., El-Khoury, V., Elazar, Z., Eldar-Finkelman, H., Elliott, C.J., Emanuele, E., Emmenegger, U., Engedal, N., Engelbrecht, 808 A.M., Engelender, S., Enserink, J.M., Erdmann, R., Erenpreisa, J., Eri, R., Eriksen, J.L., Erman, A., Escalante, R., Eskelinen, E.L., Espert, L., Esteban-Martinez, L., Evans, T.J., Fabri, M., Fabrias, G., Fabrizi, C., Facchiano, A., Faergeman, N.J., Faggioni, A., Fairlie, W.D., Fan, C., 811 Fan, D., Fan, J., Fang, S., Fanto, M., Fanzani, A., Farkas, T., Faure, M., Favier, F.B., Fearnhead, H., Federici, M., Fei, E., Felizardo, T.C., Feng, H., Feng, Y., Feng, Y., Ferguson, T.A., 813 Fernandez, A.F., Fernandez-Barrena, M.G., Fernandez-Checa, J.C., Fernandez-Lopez, A., Fernandez-Zapico, M.E., Feron, O., Ferraro, E., Ferreira-Halder, C.V., Fesus, L., Feuer, R., 815 Fiesel, F.C., Filippi-Chiela, E.C., Filomeni, G., Fimia, G.M., Fingert, J.H., Finkbeiner, S., Finkel, 816 T., Fiorito, F., Fisher, P.B., Flajolet, M., Flamigni, F., Florey, O., Florio, S., Floto, R.A., Folini, 818 A., Frankel, L.B., Fraser, I.D., Frey, N., Freyssenet, D.G., Frezza, C., Friedman, S.L., Frigo, 819 D.E., Fu, D., Fuentes, J.M., Fueyo, J., Fujitani, Y., Fujiwara, Y., Fujiya, M., Fukuda, M., Fulda, 820 S., Fusco, C., Gabryel, B., Gaestel, M., Gailly, P., Gajewska, M., Galadari, S., Galili, G., 821 Galindo, I., Galindo, M.F., Galliciotti, G., Galluzzi, L., Galluzzi, L., Galy, V., Gammoh, N., 822 Gandy, S., Ganesan, A.K., Ganesan, S., Ganley, I.G., Gannage, M., Gao, F.B., Gao, F., Gao, 823 J.X., Garcia Nannig, L., Garcia Vescovi, E., Garcia-Macia, M., Garcia-Ruiz, C., Garg, A.D., 824 Garg, P.K., Gargini, R., Gassen, N.C., Gatica, D., Gatti, E., Gavard, J., Gavathiotis, E., Ge, L., 825 Ge, P., Ge, S., Gean, P.W., Gelmetti, V., Genazzani, A.A., Geng, J., Genschik, P., Gerner, L., 826 Gestwicki, J.E., Gewirtz, D.A., Ghavami, S., Ghigo, E., Ghosh, D., Giammarioli, A.M., 827 Giampieri, F., Giampietri, C., Giatromanolaki, A., Gibbings, D.J., Gibellini, L., Gibson, S.B., 
Ginet, V., Giordano, A., Giorgini, F., Giovannetti, E., Girardin, S.E., Gispert, S., Giuliano, S., Gladson, C.L., Glavic, A., Gleave, M., Godefroy, N., Gogal, R.M., Jr., Gokulan, K., Goldman, G.H., Goletti, D., Goligorsky, M.S., Gomes, A.V., Gomes, L.C., Gomez, H., Gomez-Manzano, C., Gomez-Sanchez, R., Goncalves, D.A., Goncu, E., Gong, Q., Gongora, C., Gonzalez, C.B., Gonzalez-Alegre, P., Gonzalez-Cabo, P., Gonzalez-Polo, R.A., Goping, I.S., Gorbea, C., Gorbunov, N.V., Goring, D.R., Gorman, A.M., Gorski, S.M., Goruppi, S., Goto-Yamada, S., Gotor, C., Gottlieb, R.A., Gozes, I., Gozuacik, D., Graba, Y., Graef, M., Granato, G.E., Grant, G.D., Grant, S., Gravina, G.L., Green, D.R., Greenhough, A., Greenwood, M.T., Grimaldi, B., Gros, F., Grose, C., Groulx, J.F., Gruber, F., Grumati, P., Grune, T., Guan, J.L., Guan, K.L., Guerra, B., Guillen, C., Gulshan, K., Gunst, J., Guo, C., Guo, L., Guo, M., Guo, W., Guo, X.G., Gust, A.A., Gustafsson, A.B., Gutierrez, E., Gutierrez, M.G., Gwak, H.S., Haas, A., Haber, J.E., Hadano, S., Hagedorn, M., Hahn, D.R., Halayko, A.J., Hamacher-Brady, A., Hamada, K., Hamai, A., Hamann, A., Hamasaki, M., Hamer, I., Hamid, Q., Hammond, E.M., Han, F., Han, W., Handa, J.T., Hanover, J.A., Hansen, M., Harada, M., Harhaji-Trajkovic, L., Harper, J.W., Harrath, A.H., Harris, A.L., Harris, J., Hasler, U., Hasselblatt, P., Hasui, K., Hawley, R.G., Hawley, T.S., He, C., He, C.Y., He, F., He, G., He, R.R., He, X.H., He, Y.W., He, Y.Y., Heath, J.K., Hebert, M.J., Heinzen, R.A., Helgason, G.V., Hensel, M., Henske, E.P., Her, C., Herman, P.K., Hernandez, A., Hernandez, C., Hernandez-Tiedra, S., Hetz, C., Hiesinger, P.R., Higaki, K., Hilfiker, S., Hill, B.G., Hill, J.A., Hill, W.D., Hino, K., Hofius, D., Hofman, P., Hoglinger, G.U., Hohfeld, J., Holz, M.K., Hong, Y., Hood, D.A., Hoozemans, J.J., Hoppe, T., Hsu, C., Hsu, C.Y., Hsu, L.C., Hu, D., Hu, G., Hu, H.M., Hu, H., Hu, M.C., Hu, Y.C., Hu, Z.W., Hua, F., Hua, Y., Huang, C., Huang, H.L., Huang, K.H., Huang, K.Y., Huang, S., Huang, S., Huang, W.P., Huang, Y.R., Huang, Y., Huang, Y., Huber, T.B., Huebbe, P., Huh, W.K., Hulmi, J.J., Hur, G.M., 
851 Hurley, J.H., Husak, Z., Hussain, S.N., Hussain, S., Hwang, J.J., Hwang, S., Hwang, T.I., 852 Ichihara, A., Imai, Y., Imbriano, C., Inomata, M., Into, T., Iovane, V., Iovanna, J.L., Iozzo, R.V., 853 Ip, N.Y., Irazoqui, J.E., Iribarren, P., Isaka, Y., Isakovic, A.J., Ischiropoulos, H., Isenberg, J.S., 854 Ishaq, M., Ishida, H., Ishii, I., Ishmael, J.E., Isidoro, C., Isobe, K., Isono, E., Issazadeh-Navikas, 855 S., Itahana, K., Itakura, E., Ivanov, A.I., Iyer, A.K., Izquierdo, J.M., Izumi, Y., Izzo, V., Jaattela, 856 M., Jaber, N., Jackson, D.J., Jackson, W.T., Jacob, T.G., Jacques, T.S., Jagannath, C., Jain, A., 857 Jana, N.R., Jang, B.K., Jani, A., Janji, B., Jannig, P.R., Jansson, P.J., Jean, S., Jendrach, M., 858 Jeon, J.H., Jessen, N., Jeung, E.B., Jia, K., Jia, L., Jiang, H., Jiang, H., Jiang, L., Jiang, T., Jiang, 859 X., Jiang, X., Jiang, X., Jiang, Y., Jiang, Y., Jimenez, A., Jin, C., Jin, H., Jin, L., Jin, M., Jin, S., 860 Jinwal, U.K., Jo, E.K., Johansen, T., Johnson, D.E., Johnson, G.V., Johnson, J.D., Jonasch, E., 861 Jones, C., Joosten, L.A., Jordan, J., Joseph, A.M., Joseph, B., Joubert, A.M., Ju, D., Ju, J., Juan, 862 H.F., Juenemann, K., Juhasz, G., Jung, H.S., Jung, J.U., Jung, Y.K., Jungbluth, H., Justice, M.J., 863 Jutten, B., Kaakoush, N.O., Kaarniranta, K., Kaasik, A., Kabuta, T., Kaeffer, B., Kagedal, K., 864 Kahana, A., Kajimura, S., Kakhlon, O., Kalia, M., Kalvakolanu, D.V., Kamada, Y., Kambas, K., 865 Kaminskyy, V.O., Kampinga, H.H., Kandouz, M., Kang, C., Kang, R., Kang, T.C., Kanki, T., 866 Kanneganti, T.D., Kanno, H., Kanthasamy, A.G., Kantorow, M., Kaparakis-Liaskos, M., Kapuy, 867 O., Karantza, V., Karim, M.R., Karmakar, P., Kaser, A., Kaushik, S., Kawula, T., Kaynar, A.M., 868 Ke, P.Y., Ke, Z.J., Kehrl, J.H., Keller, K.E., Kemper, J.K., Kenworthy, A.K., Kepp, O., Kern, A., 869 Kesari, S., Kessel, D., Ketteler, R., Kettelhut Ido, C., Khambu, B., Khan, M.M., Khandelwal, 870 V.K., Khare, S., Kiang, J.G., Kiger, A.A., Kihara, A., Kim, A.L., Kim, C.H., Kim, D.R., Kim, 871 D.H., Kim, E.K., Kim, H.Y., Kim, H.R., Kim, J.S., Kim, J.H., Kim, J.C., Kim, J.H., Kim, K.W., 872 Kim, M.D., Kim, M.M., Kim, P.K., Kim, S.W., Kim, S.Y., Kim, Y.S., Kim, Y., Kimchi, A., 873 Kimmelman, A.C., Kimura, T., King, J.S., Kirkegaard, K., Kirkin, V., Kirshenbaum, L.A., Kishi, 
S., Kitajima, Y., Kitamoto, K., Kitaoka, Y., Kitazato, K., Kley, R.A., Klimecki, W.T., Klinkenberg, M., Klucken, J., Knaevelsrud, H., Knecht, E., Knuppertz, L., Ko, J.L., Kobayashi, S., Koch, J.C., Koechlin-Ramonatxo, C., Koenig, U., Koh, Y.H., Kohler, K., Kohlwein, S.D., Koike, M., Komatsu, M., Kominami, E., Kong, D., Kong, H.J., Konstantakou, E.G., Kopp, B.T., Korcsmaros, T., Korhonen, L., Korolchuk, V.I., Koshkina, N.V., Kou, Y., Koukourakis, M.I., Koumenis, C., Kovacs, A.L., Kovacs, T., Kovacs, W.J., Koya, D., Kraft, C., Krainc, D., Kramer, H., Kravic-Stevovic, T., Krek, W., Kretz-Remy, C., Krick, R., Krishnamurthy, M., Kriston-Vizi, J., Kroemer, G., Kruer, M.C., Kruger, R., Ktistakis, N.T., Kuchitsu, K., Kuhn, C., Kumar, A.P., Kumar, A., Kumar, A., Kumar, D., Kumar, D., Kumar, R., Kumar, S., Kundu, M., Kung, H.J., Kuno, A., Kuo, S.H., Kuret, J., Kurz, T., Kwok, T., Kwon, T.K., Kwon, Y.T., Kyrmizi, I., La Spada, A.R., Lafont, F., Lahm, T., Lakkaraju, A., Lam, T., Lamark, T., Lancel, S., Landowski, T.H., Lane, D.J., Lane, J.D., Lanzi, C., Lapaquette, P., Lapierre, L.R., Laporte, J., Laukkarinen, J., Laurie, G.W., Lavandero, S., Lavie, L., LaVoie, M.J., Law, B.Y., Law, H.K., Law, K.B., Layfield, R., Lazo, P.A., Le Cam, L., Le Roch, K.G., Le Stunff, H., Leardkamolkarn, V., Lecuit, M., Lee, B.H., Lee, C.H., Lee, E.F., Lee, G.M., Lee, H.J., Lee, H., Lee, J.K., Lee, J., Lee, J.H., Lee, J.H., Lee, M., Lee, M.S., Lee, P.J., Lee, S.W., Lee, S.J., Lee, S.J., Lee, S.Y., Lee, S.H., Lee, S.S., Lee, S.J., Lee, S., Lee, Y.R., Lee, Y.J., Lee, Y.H., Leeuwenburgh, C., Lefort, S., Legouis, R., Lei, J., Lei, Q.Y., Leib, D.A., Leibowitz, G., Lekli, I., Lemaire, S.D., Lemasters, J.J., Lemberg, M.K., Lemoine, A., Leng, S., Lenz, G., Lenzi, P., Lerman, L.O., Lettieri Barbato, D., Leu, J.I., Leung, H.Y., Levine, B., Lewis, P.A., Lezoualc'h, F., Li, C., Li, F., Li, F.J., Li, J., Li, K., Li, L., Li, M., Li, M., Li, Q., Li, R., Li, S., Li, W., Li, W., Li, X., Li, Y., Lian, J., Liang, C., Liang, Q., Liao, Y., Liberal, J., Liberski, P.P., Lie, P., Lieberman, A.P., Lim, H.J., Lim, K.L., Lim, K., Lima, R.T., Lin, C.S., Lin, C.F., Lin, F., Lin, F., Lin, F.C., Lin, K., Lin, K.H., Lin, P.H., 
Lin, T., Lin, W.W., Lin, Y.S., Lin, Y., Linden, R., Lindholm, D., Lindqvist, L.M., Lingor, P., Linkermann, A., Liotta, L.A., Lipinski, M.M., Lira, V.A., Lisanti, M.P., Liton, P.B., Liu, B., Liu, C., Liu, C.F., Liu, F., Liu, H.J., Liu, J., Liu, J.J., Liu, J.L., Liu, K., Liu, L., Liu, L., Liu, Q., Liu, R.Y., Liu, S., Liu, S., Liu, W., Liu, X.D., Liu, X., Liu, X.H., Liu, X., Liu, X., Liu, X., Liu, Y., Liu, Y., Liu, Z., Liu, Z., Liuzzi, J.P., Lizard, G., Ljujic, M., Lodhi, I.J., Logue, S.E., Lokeshwar, B.L., Long, Y.C., Lonial, S., Loos, B., Lopez-Otin, C., Lopez-Vicario, C., Lorente, M., Lorenzi, 903 P.L., Lorincz, P., Los, M., Lotze, M.T., Lovat, P.E., Lu, B., Lu, B., Lu, J., Lu, Q., Lu, S.M., Lu, S., Lu, Y., Luciano, F., Luckhart, S., Lucocq, J.M., Ludovico, P., Lugea, A., Lukacs, N.W., Lum, 905 J.J., Lund, A.H., Luo, H., Luo, J., Luo, S., Luparello, C., Lyons, T., Ma, J., Ma, Y., Ma, Y., Ma, 906 Z., Machado, J., Machado-Santelli, G.M., Macian, F., MacIntosh, G.C., MacKeigan, J.P., 907 Macleod, K.F., MacMicking, J.D., MacMillan-Crow, L.A., Madeo, F., Madesh, M., Madrigal908 Matute, J., Maeda, A., Maeda, T., Maegawa, G., Maellaro, E., Maes, H., Magarinos, M., Maiese, K., Maiti, T.K., Maiuri, L., Maiuri, M.C., Maki, C.G., Malli, R., Malorni, W., Maloyan, A., Mami-Chouaib, F., Man, N., Mancias, J.D., Mandelkow, E.M., Mandell, M.A., Manfredi, A.A., Manie, S.N., Manzoni, C., Mao, K., Mao, Z., Mao, Z.W., Marambaud, P., Marconi, A.M., 912 Marelja, Z., Marfe, G., Margeta, M., Margittai, E., Mari, M., Mariani, F.V., Marin, C., Marinelli, S., Marino, G., Markovic, I., Marquez, R., Martelli, A.M., Martens, S., Martin, K.R., Martin, 914 S.J., Martin, S., Martin-Acebes, M.A., Martin-Sanz, P., Martinand-Mari, C., Martinet, W., 915 Martinez, J., Martinez-Lopez, N., Martinez-Outschoorn, U., Martinez-Velazquez, M., MartinezVicente, M., Martins, W.K., Mashima, H., Mastrianni, J.A., Matarese, G., Matarrese, P., Mateo, R., Matoba, S., Matsumoto, N., Matsushita, T., Matsuura, A., Matsuzawa, T., Mattson, M.P., Matus, S., Maugeri, N., Mauvezin, C., Mayer, A., Maysinger, D., Mazzolini, G.D., McBrayer, 
J.J., McNeish, I.A., Mechta-Grigoriou, F., Medema, J.P., Medina, D.L., Megyeri, K., Mehrpour, M., Mehta, J.L., Mei, Y., Meier, U.C., Meijer, A.J., Melendez, A., Melino, G., Melino, S., de Melo, E.J., Mena, M.A., Meneghini, M.D., Menendez, J.A., Menezes, R., Meng, L., Meng, L.H., Meng, S., Menghini, R., Menko, A.S., Menna-Barreto, R.F., Menon, M.B., Meraz-Rios, M.A., Merla, G., Merlini, L., Merlot, A.M., Meryk, A., Meschini, S., Meyer, J.N., Mi, M.T., Miao, C.Y., Micale, L., Michaeli, S., Michiels, C., Migliaccio, A.R., Mihailidou, A.S., Mijaljica, D., Mikoshiba, K., Milan, E., Miller-Fleming, L., Mills, G.B., Mills, I.G., Minakaki, G., Minassian, B.A., Ming, X.F., Minibayeva, F., Minina, E.A., Mintern, J.D., Minucci, S., Miranda-Vizuete, A., Mitchell, C.H., Miyamoto, S., Miyazawa, K., Mizushima, N., Mnich, K., Mograbi, B., Mohseni, S., Moita, L.F., Molinari, M., Molinari, M., Moller, A.B., Mollereau, B., Mollinedo, F., Mongillo, M., Monick, M.M., Montagnaro, S., Montell, C., Moore, D.J., Moore, M.N., MoraRodriguez, R., Moreira, P.I., Morel, E., Morelli, M.B., Moreno, S., Morgan, M.J., Moris, A., Moriyasu, Y., Morrison, J.L., Morrison, L.A., Morselli, E., Moscat, J., Moseley, P.L., Mostowy, S., Motori, E., Mottet, D., Mottram, J.C., Moussa, C.E., Mpakou, V.E., Mukhtar, H., Mulcahy Levy, J.M., Muller, S., Munoz-Moreno, R., Munoz-Pinedo, C., Munz, C., Murphy, M.E., Murray, J.T., Murthy, A., Mysorekar, I.U., Nabi, I.R., Nabissi, M., Nader, G.A., Nagahara, Y., Nagai, Y., Nagata, K., Nagelkerke, A., Nagy, P., Naidu, S.R., Nair, S., Nakano, H., Nakatogawa, H., Nanjundan, M., Napolitano, G., Naqvi, N.I., Nardacci, R., Narendra, D.P., Narita, M., Nascimbeni, A.C., Natarajan, R., Navegantes, L.C., Nawrocki, S.T., Nazarko, T.Y., Nazarko, V.Y., Neill, T., Neri, L.M., Netea, M.G., Netea-Maier, R.T., Neves, B.M., Ney, P.A., Nezis, I.P., Nguyen, H.T., Nguyen, H.P., Nicot, A.S., Nilsen, H., Nilsson, P., Nishimura, M., Nishino, I., Niso-Santano, M., Niu, H., Nixon, R.A., Njar, V.C., Noda, T., Noegel, A.A., Nolte, E.M., Norberg, E., Norga, K.K., Noureini, S.K., Notomi, S., Notterpek, L., Nowikovsky, K., Nukina, 
N., Nurnberger, T., O'Donnell, V.B., O'Donovan, T., O'Dwyer, P.J., Oehme, I., Oeste, C.L., Ogawa, M., Ogretmen, B., Ogura, Y., Oh, Y.J., Ohmuraya, M., Ohshima, T., Ojha, R., Okamoto, K., Okazaki, T., Oliver, F.J., Ollinger, K., Olsson, S., Orban, D.P., Ordonez, P., Orhon, I., Orosz, L., O'Rourke, E.J., Orozco, H., Ortega, A.L., Ortona, E., Osellame, L.D., Oshima, J., Oshima, S., Osiewacz, H.D., Otomo, T., Otsu, K., Ou, J.H., Outeiro, T.F., Ouyang, D.Y., Ouyang, H., Overholtzer, M., Ozbun, M.A., Ozdinler, P.H., Ozpolat, B., Pacelli, C., Paganetti, P., Page, G., Pages, G., Pagnini, U., Pajak, B., Pak, S.C., Pakos-Zebrucka, K., Pakpour, N., Palkova, Z., Palladino, F., Pallauf, K., Pallet, N., Palmieri, M., Paludan, S.R., Palumbo, C., Palumbo, S., Pampliega, O., Pan, H., Pan, W., Panaretakis, T., Pandey, A., Pantazopoulou, A., Papackova, Z., Papademetrio, D.L., Papassideri, I., Papini, A., Parajuli, N., Pardo, J., Parekh, V.V., Parenti, G., Park, J.I., Park, J., Park, O.K., Parker, R., Parlato, R., Parys, J.B., Parzych, K.R., Pasquet, J.M., Pasquier, B., Pasumarthi, K.B., Patschan, D., Patterson, C., Pattingre, S., Pattison, S., Pause, A., Pavenstadt, H., Pavone, F., Pedrozo, Z., Pena, F.J., Penalva, M.A., Pende, M., Peng, J., Penna, F., Penninger, J.M., Pensalfini, A., Pepe, S., Pereira, G.J., Pereira, P.C., Perez-de la Cruz, V., Perez-Perez, M.E., Perez-Rodriguez, D., Perez-Sala, D., Perier, C., Perl, A., Perlmutter, D.H., Perrotta, I., Pervaiz, S., Pesonen, M., Pessin, J.E., Peters, G.J., Petersen, M., Petrache, I., Petrof, B.J., Petrovski, G., Phang, J.M., Piacentini, M., Pierdominici, M., Pierre, P., Pierrefite-Carle, V., Pietrocola, F., Pimentel-Muinos, F.X., Pinar, M., Pineda, B., Pinkas-Kramarski, R., Pinti, M., Pinton, P., Piperdi, B., Piret, J.M., Platanias, L.C., Platta, H.W., Plowey, E.D., Poggeler, S., Poirot, M., Polcic, P., Poletti, A., Poon, A.H., Popelka, H., Popova, B., Poprawa, I., Poulose, S.M., Poulton, J., Powers, S.K., Powers, T., Pozuelo-Rubio, M., Prak, K., Prange, R., Prescott, M., Priault, M., Prince, S., Proia, R.L., Proikas-Cezanne, T., Prokisch, H., Promponas, V.J., Przyklenk, K., Puertollano, R., Pugazhenthi, S., Puglielli, L., Pujol, A., Puyal, J., Pyeon, D., Qi, 
X., Qian, W.B., Qin, Z.H., Qiu, Y., Qu, Z., Quadrilatero, J., Quinn, F., Raben, N., Rabinowich,

H., Radogna, F., Ragusa, M.J., Rahmani, M., Raina, K., Ramanadham, S., Ramesh, R., Rami, A.,

Randall-Demllo, S., Randow, F., Rao, H., Rao, V.A., Rasmussen, B.B., Rasse, T.M., Ratovitski,

E.A., Rautou, P.E., Ray, S.K., Razani, B., Reed, B.H., Reggiori, F., Rehm, M., Reichert, A.S.,

L., Rezaie, A.R., Richards, R.I., Richardson, D.R., Richetta, C., Riehle, M.A., Rihn, B.H.,

972

Rikihisa, Y., Riley, B.E., Rimbach, G., Rippo, M.R., Ritis, K., Rizzi, F., Rizzo, E., Roach, P.J.,

973

Robbins, J., Roberge, M., Roca, G., Roccheri, M.C., Rocha, S., Rodrigues, C.M., Rodriguez,

974

C.I., de Cordoba, S.R., Rodriguez-Muela, N., Roelofs, J., Rogov, V.V., Rohn, T.T., Rohrer, B.,

Romanelli, D., Romani, L., Romano, P.S., Roncero, M.I., Rosa, J.L., Rosello, A., Rosen, K.V.,

Rosenstiel, P., Rost-Roszkowska, M., Roth, K.A., Roue, G., Rouis, M., Rouschop, K.M., Ruan,

D.T., Ruano, D., Rubinsztein, D.C., Rucker, E.B., 3rd, Rudich, A., Rudolf, E., Rudolf, R.,

978 Ruegg, M.A., Ruiz-Roldan, C., Ruparelia, A.A., Rusmini, P., Russ, D.W., Russo, G.L., Russo,

979

G., Russo, R., Rusten, T.E., Ryabovol, V., Ryan, K.M., Ryter, S.W., Sabatini, D.M., Sacher, M.,

Sachse, C., Sack, M.N., Sadoshima, J., Saftig, P., Sagi-Eisenberg, R., Sahni, S., Saikumar, P.,

Saito, T., Saitoh, T., Sakakura, K., Sakoh-Nakatogawa, M., Sakuraba, Y., Salazar-Roa, M.,

Salomoni, P., Saluja, A.K., Salvaterra, P.M., Salvioli, R., Samali, A., Sanchez, A.M., Sanchez-

Alcazar, J.A., Sanchez-Prieto, R., Sandri, M., Sanjuan, M.A., Santaguida, S., Santambrogio, L.,

Santoni, G., Dos Santos, C.N., Saran, S., Sardiello, M., Sargent, G., Sarkar, P., Sarkar, S.,

985 Sarrias, M.R., Sarwal, M.M., Sasakawa, C., Sasaki, M., Sass, M., Sato, K., Sato, M., Satriano, J., 986

Savaraj, N., Saveljeva, S., Schaefer, L., Schaible, U.E., Scharl, M., Schatzl, H.M., Schekman, R.,

987 Scheper, W., Schiavi, A., Schipper, H.M., Schmeisser, H., Schmidt, J., Schmitz, I., Schneider,

988 B.E., Schneider, E.M., Schneider, J.L., Schon, E.A., Schonenberger, M.J., Schonthal, A.H., 
Schorderet, D.F., Schroder, B., Schuck, S., Schulze, R.J., Schwarten, M., Schwarz, T.L., Sciarretta, S., Scotto, K., Scovassi, A.I., Screaton, R.A., Screen, M., Seca, H., Sedej, S., Segatori, L., Segev, N., Seglen, P.O., Segui-Simarro, J.M., Segura-Aguilar, J., Seki, E., Sell, C., Seiliez, I., Semenkovich, C.F., Semenza, G.L., Sen, U., Serra, A.L., Serrano-Puebla, A., Sesaki, H., Setoguchi, T., Settembre, C., Shacka, J.J., Shajahan-Haq, A.N., Shapiro, I.M., Sharma, S., She, H., Shen, C.K., Shen, C.C., Shen, H.M., Shen, S., Shen, W., Sheng, R., Sheng, X., Sheng, Z.H., Shepherd, T.G., Shi, J., Shi, Q., Shi, Q., Shi, Y., Shibutani, S., Shibuya, K., Shidoji, Y., Shieh, J.J., Shih, C.M., Shimada, Y., Shimizu, S., Shin, D.W., Shinohara, M.L., Shintani, M., Shintani, T., Shioi, T., Shirabe, K., Shiri-Sverdlov, R., Shirihai, O., Shore, G.C., Shu, C.W., Shukla, D., Sibirny, A.A., Sica, V., Sigurdson, C.J., Sigurdsson, E.M., Sijwali, P.S., Sikorska, B., Silveira, W.A., Silvente-Poirot, S., Silverman, G.A., Simak, J., Simmet, T., Simon, A.K., Simon, H.U., Simone, C., Simons, M., Simonsen, A., Singh, R., Singh, S.V., Singh, S.K., Sinha, D., Sinha, S., Sinicrope, F.A., Sirko, A., Sirohi, K., Sishi, B.J., Sittler, A., Siu, P.M., Sivridis, E., Skwarska, A., Slack, R., Slaninova, I., Slavov, N., Smaili, S.S., Smalley, K.S., Smith, D.R., Soenen, S.J., Soleimanpour, S.A., Solhaug, A., Somasundaram, K., Son, J.H., Sonawane, A., Song, C., Song, F., Song, H.K., Song, J.X., Song, W., Soo, K.Y., Sood, A.K., Soong, T.W., Soontornniyomkij, V., Sorice, M., Sotgia, F., Soto-Pantoja, D.R., Sotthibundhu, A., Sousa, M.J., Spaink, H.P., Span, P.N., Spang, A., Sparks, J.D., Speck, P.G., Spector, S.A., Spies, C.D., Springer, W., Clair, D.S., Stacchiotti, A., Staels, B., Stang, M.T., Starczynowski, D.T., Starokadomskyy, P., Steegborn, C., Steele, J.W., Stefanis, L., Steffan, J., Stellrecht, C.M., Stenmark, H., Stepkowski, T.M., Stern, S.T., Stevens, C., Stockwell, B.R., Stoka, V., Storchova, Z., Stork, B., Stratoulias, V., Stravopodis, D.J., Strnad, P., Strohecker, A.M., Strom, A.L., Stromhaug, P., Stulik, J., Su, Y.X., Su, Z., Subauste, C.S., Subramaniam, S., Sue, C.M., Suh, S.W., Sui, X., Sukseree, S., Sulzer, D., 
1012

1013

1014

1015

1016

1017

1018

1019

1020

1021

1022

1023

1024

1025

1026

1027

1028

1029

1030

1031

1032

1033

1034

Sun, F.L., Sun, J., Sun, J., Sun, S.Y., Sun, Y., Sun, Y., Sun, Y., Sundaramoorthy, V., Sung, J.,

Suzuki, H., Suzuki, K., Suzuki, N., Suzuki, T., Suzuki, Y.J., Swanson, M.S., Swanton, C.,

Sward, K., Swarup, G., Sweeney, S.T., Sylvester, P.W., Szatmari, Z., Szegezdi, E., Szlosarek, P.W., Taegtmeyer, H., Tafani, M., Taillebourg, E., Tait, S.W., Takacs-Vellai, K., Takahashi, Y., Takats, S., Takemura, G., Takigawa, N., Talbot, N.J., Tamagno, E., Tamburini, J., Tan, C.P., Tan, L., Tan, M.L., Tan, M., Tan, Y.J., Tanaka, K., Tanaka, M., Tang, D., Tang, D., Tang, G., Tanida, I., Tanji, K., Tannous, B.A., Tapia, J.A., Tasset-Cuevas, I., Tatar, M., Tavassoly, I., Tavernarakis, N., Taylor, A., Taylor, G.S., Taylor, G.A., Taylor, J.P., Taylor, M.J., Tchetina, E.V., Tee, A.R., Teixeira-Clerc, F., Telang, S., Tencomnao, T., Teng, B.B., Teng, R.J., Terro, F., Tettamanti, G., Theiss, A.L., Theron, A.E., Thomas, K.J., Thome, M.P., Thomes, P.G., Thorburn, A., Thorner, J., Thum, T., Thumm, M., Thurston, T.L., Tian, L., Till, A., Ting, J.P., Titorenko, V.I., Toker, L., Toldo, S., Tooze, S.A., Topisirovic, I., Torgersen, M.L., Torosantucci, L., Torriglia, A., Torrisi, M.R., Tournier, C., Towns, R., Trajkovic, V., Travassos, L.H., Triola, G., Tripathi, D.N., Trisciuoglio, D., Troncoso, R., Trougakos, I.P., Truttmann, A.C., Tsai, K.J., Tschan, M.P., Tseng, Y.H., Tsukuba, T., Tsung, A., Tsvetkov, A.S., Tu, S., Tuan, H.Y., Tucci, M., Tumbarello, D.A., Turk, B., Turk, V., Turner, R.F., Tveita, A.A., Tyagi, S.C., Ubukata, M., Uchiyama, Y., Udelnow, A., Ueno, T., Umekawa, M., Umemiya-Shirafuji, R., Underwood, B.R., Ungermann, C., Ureshino, R.P., Ushioda, R., Uversky, V.N., Uzcategui, N.L., Vaccari, T., Vaccaro, M.I., Vachova, L., Vakifahmetoglu-Norberg, H., Valdor, R., Valente, E.M., Vallette, F., Valverde, A.M., Van den Berghe, G., Van Den Bosch, L., van den Brink, G.R., van der Goot, F.G., van der Klei, I.J., van der Laan, L.J., van Doorn, W.G., van Egmond, M., van Golen, K.L., Van Kaer, L., van Lookeren Campagne, M., Vandenabeele, P., Vandenberghe, W., Vanhorebeek, I., Varela-Nieto, I., Vasconcelos, M.H., Vasko, R., Vavvas, D.G., Vega-Naredo, I., Velasco, G., 
Velentzas, A.D., Velentzas, P.D., Vellai, T., Vellenga, E., Vendelbo, M.H., Venkatachalam, K., Ventura, N., Ventura, S., Veras, P.S., Verdier, M., Vertessy, B.G., Viale, A., Vidal, M., Vieira, H.L., Vierstra, R.D., Vigneswaran, N., Vij, N., Vila, M., Villar, M., Villar, V.H., Villarroya, J., Vindis, C., Viola, G., Viscomi, M.T., Vitale, G., Vogl, D.T., Voitsekhovskaja, O.V., von Haefen, C., von Schwarzenberg, K., Voth, D.E., Vouret-Craviari, V., Vuori, K., Vyas, J.M., Waeber, C., Walker, C.L., Walker, M.J., Walter, J., Wan, L., Wan, X., Wang, B., Wang, C., Wang, C.Y., Wang, C., Wang, C., Wang, C., Wang, D., Wang, F., Wang, F., Wang, G., Wang, H.J., Wang, H., Wang, H.G., Wang, H., Wang, H.D., Wang, J., Wang, J., Wang, M., Wang, M.Q., Wang, P.Y., Wang, P., Wang, R.C., Wang, S., Wang, T.F., Wang, X., Wang, X.J., Wang, X.W., Wang, X., Wang, X., Wang, Y., Wang, Y., Wang, Y., Wang, Y.J., Wang, Y., Wang, Y., Wang, Y.T., Wang, Y., Wang, Z.N., Wappner, P., Ward, C., Ward, D.M., Warnes, G., Watada, H., Watanabe, Y., Watase, K., Weaver, T.E., Weekes, C.D., Wei, J., Weide, T., Weihl, C.C., Weindl, G., Weis, S.N., Wen, L., Wen, X., Wen, Y., Westermann, B., Weyand, C.M., White, A.R., White, E., Whitton, J.L., Whitworth, A.J., Wiels, J., Wild, F., Wildenberg, M.E., Wileman, T., Wilkinson, D.S., Wilkinson, S., Willbold, D., Williams, C., Williams, K., Williamson, P.R., Winklhofer, K.F., Witkin, S.S., Wohlgemuth, S.E., Wollert, T., Wolvetang, E.J., Wong, E., Wong, G.W., Wong, R.W., Wong, V.K., Woodcock, E.A., Wright, K.L., Wu, C., Wu, D., Wu, G.S., Wu, J., Wu, J., Wu, M., Wu, M., Wu, S., Wu, W.K., Wu, Y., Wu, Z., Xavier, C.P., Xavier, R.J., Xia, G.X., Xia, T., Xia, W., Xia, Y., Xiao, H., Xiao, J., Xiao, S., Xiao, W., Xie, C.M., Xie, Z., Xie, Z., Xilouri, M., Xiong, Y., Xu, C., Xu, C., Xu, F., Xu, H., Xu, H., Xu, J., Xu, J., Xu, J., Xu, L., Xu, X., Xu, Y., Xu, Y., Xu, Z.X., Xu, Z., Xue, Y., Yamada, T., Yamamoto, A., Yamanaka, K., Yamashina, S., Yamashiro, S., Yan, B., Yan, B., Yan, X., Yan, Z., Yanagi, Y., Yang, D.S., Yang, J.M., Yang, L., Yang, M., Yang, P.M., Yang, P., Yang, Q., Yang, W., Yang, W.Y., Yang, 
X., Yang, Y., Yang, Y., Yang, Z., Yang, Z., Yao, M.C., Yao, P.J., Yao, X., Yao, Z., Yao, Z., Yasui, L.S., Ye, M., Yedvobnick, B., Yeganeh, B., Yeh, E.S., Yeyati, P.L., Yi, F., Yi, L., Yin, X.M., Yip, C.K., Yoo, Y.M., Yoo, Y.H., Yoon, S.Y., Yoshida, K., Yoshimori, T., Young, K.H., Yu, H., Yu, J.J., Yu, J.T., Yu, J., Yu, L., Yu, W.H., Yu, X.F., Yu, Z., Yuan, J., Yuan, Z.M., Yue, B.Y., Yue, J., Yue, Z., Zacks, D.N., Zacksenhaus, E., Zaffaroni, N., Zaglia, T., Zakeri, Z., Zecchini, V., Zeng, J., Zeng, M., Zeng, Q., Zervos, A.S., Zhang, D.D., Zhang, F., Zhang, G., Zhang, G.C., Zhang, H., Zhang, H., Zhang, H., Zhang, H., Zhang, J., Zhang, J., Zhang, J., Zhang, J., Zhang, J.P., Zhang, L., Zhang, L., Zhang, L., Zhang, L., Zhang, M.Y., Zhang, X., Zhang, X.D., Zhang, Y., Zhang, Y., Zhang, Y., Zhang, Y., Zhang, Y., Zhao, M., Zhao, W.L., Zhao, X., Zhao, Y.G., Zhao, Y., Zhao, Y., Zhao, Y.X., Zhao, Z., Zhao, Z.J., Zheng, D., Zheng, X.L., Zheng, X., Zhivotovsky, B., Zhong, Q., Zhou, G.Z., Zhou, G., Zhou, H., Zhou, S.F., Zhou, X.J., Zhu, H., Zhu, H., Zhu, W.G., Zhu, W., Zhu, X.F., Zhu, Y., Zhuang, S.M., Zhuang, X., Ziparo, E., Zois, C.E., Zoladek, T., Zong, W.X., Zorzano, A., Zughaier, S.M., 2016. Guidelines for the use and interpretation of assays for monitoring autophagy (3rd edition). Autophagy 12, 1-222.

Kobayashi, M., Otsuka, Y., Itagaki, S., Hirano, T., Iseki, K., 2006. Inhibitory effects of statins on human monocarboxylate transporter 4. International journal of pharmaceutics 317, 19-25.

Kobayashi, Y., Kashima, H., Rahmanto, Y.S., Banno, K., Yu, Y., Matoba, Y., Watanabe, K., Iijima, M., Takeda, T., Kunitomi, H., Iida, M., Adachi, M., Nakamura, K., Tsuji, K., Masuda, K., Nomura, H., Tominaga, E., Aoki, D., 2017. Drug repositioning of mevalonate pathway inhibitors as antitumor agents for ovarian cancer. Oncotarget 8, 72147-72156.

Kobayashi, Y., Kashima, H., Wu, R.C., Jung, J.G., Kuan, J.C., Gu, J., Xuan, J., Sokoll, L., Visvanathan, K., Shih Ie, M., Wang, T.L., 2015. Mevalonate Pathway Antagonist Suppresses Formation of Serous Tubal Intraepithelial Carcinoma and Ovarian Carcinoma in Mouse Models. 
1081 Clinical cancer research : an official journal of the American Association for Cancer Research $1082 \quad 21,4652-4662$.

1083 Kwak, H.B., Thalacker-Mercer, A., Anderson, E.J., Lin, C.T., Kane, D.A., Lee, N.S., Cortright, 1084 R.N., Bamman, M.M., Neufer, P.D., 2012. Simvastatin impairs ADP-stimulated respiration and 1085 increases mitochondrial oxidative stress in primary human skeletal myotubes. Free radical 1086 biology \& medicine 52, 198-207.

1087 Levinger, I., Ventura, Y., Vago, R., 2014. Life is three dimensional-as in vitro cancer cultures 1088 should be. Advances in cancer research 121, 383-414.

1089 Liu, G., Pei, F., Yang, F., Li, L., Amin, A.D., Liu, S., Buchan, J.R., Cho, W.C., 2017. Role of 1090 Autophagy and Apoptosis in Non-Small-Cell Lung Cancer. Int J Mol Sci 18.

1091 Ma, X.H., Piao, S., Wang, D., McAfee, Q.W., Nathanson, K.L., Lum, J.J., Li, L.Z., Amaravadi, 1092 R.K., 2011. Measurements of tumor cell autophagy predict invasiveness, resistance to 1093 chemotherapy, and survival in melanoma. Clinical cancer research : an official journal of the 1094 American Association for Cancer Research 17, 3478-3489.

1095 Matzno, S., Yamauchi, T., Gohda, M., Ishida, N., Katsuura, K., Hanasaki, Y., Tokunaga, T., 1096 Itoh, H., Nakamura, N., 1997. Inhibition of cholesterol biosynthesis by squalene epoxidase 1097 inhibitor avoids apoptotic cell death in L6 myoblasts. J Lipid Res 38, 1639-1648.

1098 Mehrbod, P., Ande, S.R., Alizadeh, J., Rahimizadeh, S., Shariati, A., Malek, H., Hashemi, M., 1099 Glover, K.K.M., Sher, A.A., Coombs, K.M., Ghavami, S., 2019. The roles of apoptosis, 1100 autophagy and unfolded protein response in arbovirus, influenza virus, and HIV infections. 1101 Virulence 10, 376-413.

1102 Mizushima, N., Yoshimori, T., Levine, B., 2010. Methods in mammalian autophagy research. 1103 Cell 140, 313-326. 
1104 Moghadam, A.R., da Silva Rosa, S.C., Samiei, E., Alizadeh, J., Field, J., Kawalec, P., Thliveris, 1105 J., Akbari, M., Ghavami, S., Gordon, J.W., 2018. Autophagy modulates temozolomide-induced 1106 cell death in alveolar Rhabdomyosarcoma cells. Cell Death Discov 4, 52.

1107 Mokarram, P., Albokashy, M., Zarghooni, M., Moosavi, M.A., Sepehri, Z., Chen, Q.M., 1108 Hudecki, A., Sargazi, A., Alizadeh, J., Moghadam, A.R., Hashemi, M., Movassagh, H., 1109 Klonisch, T., Owji, A.A., Los, M.J., Ghavami, S., 2017. New frontiers in the treatment of 1110 colorectal cancer: Autophagy and the unfolded protein response as promising targets. Autophagy $1111 \quad 13,781-819$

1112 Mullen, P.J., Luscher, B., Scharnagl, H., Krahenbuhl, S., Brecht, K., 2010. Effect of simvastatin 1113 on cholesterol metabolism in $\mathrm{C} 2 \mathrm{C} 12$ myotubes and HepG2 cells, and consequences for statin1114 induced myopathy. Biochemical pharmacology 79, 1200-1209.

1115 Pankiv, S., Clausen, T.H., Lamark, T., Brech, A., Bruun, J.A., Outzen, H., Overvatn, A., 1116 Bjorkoy, G., Johansen, T., 2007. p62/SQSTM1 binds directly to Atg8/LC3 to facilitate 1117 degradation of ubiquitinated protein aggregates by autophagy. The Journal of biological 1118 chemistry 282, 24131-24145.

1119 Prueksaritanont, T., Tang, C., Qiu, Y., Mu, L., Subramanian, R., Lin, J.H., 2002. Effects of 1120 fibrates on metabolism of statins in human hepatocytes. Drug metabolism and disposition: the 1121 biological fate of chemicals 30, 1280-1287.

1122 Sakamoto, K., Honda, T., Yokoya, S., Waguri, S., Kimura, J., 2007. Rab-small GTPases are 1123 involved in fluvastatin and pravastatin-induced vacuolation in rat skeletal myofibers. FASEB 1124 journal : official publication of the Federation of American Societies for Experimental Biology $1125 \quad 21,4087-4094$. 
1126 Schirris, T.J., Renkema, G.H., Ritschel, T., Voermans, N.C., Bilos, A., van Engelen, B.G., 1127 Brandt, U., Koopman, W.J., Beyrath, J.D., Rodenburg, R.J., Willems, P.H., Smeitink, J.A., 1128 Russel, F.G., 2015a. Statin-Induced Myopathy Is Associated with Mitochondrial Complex III 1129 Inhibition. Cell Metab 22, 399-407.

1130 Schirris, T.J., Ritschel, T., Herma Renkema, G., Willems, P.H., Smeitink, J.A., Russel, F.G., 1131 2015b. Mitochondrial ADP/ATP exchange inhibition: a novel off-target mechanism underlying 1132 ibipinabant-induced myotoxicity. Scientific reports 5, 14533.

1133 Seyfoori, A., Samiei, E., Jalili, N., Godau, B., Rahmanian, M., Farahmand, L., Majidzadeh, 1134 A.K., Akbari, M., 2018. Self-filling microwell arrays (SFMAs) for tumor spheroid formation. 1135 Lab Chip 18, 3516-3528.

1136 Sheikholeslami, K., Ali Sher, A., Lockman, S., Kroft, D., Ganjibakhsh, M., Nejati-Koshki, K., 1137 Shojaei, S., Ghavami, S., Rastegar, M., 2019. Simvastatin Induces Apoptosis in 1138 Medulloblastoma Brain Tumor Cells via Mevalonate Cascade Prenylation Substrates. Cancers 1139 (Basel) 11.

1140 Siddals, K.W., Marshman, E., Westwood, M., Gibson, J.M., 2004. Abrogation of insulin-like 1141 growth factor-I (IGF-I) and insulin action by mevalonic acid depletion: synergy between protein 1142 prenylation and receptor glycosylation pathways. The Journal of biological chemistry 279, $1143 \quad 38353-38359$.

1144 Sirvent, P., Fabre, O., Bordenave, S., Hillaire-Buys, D., Raynaud De Mauverger, E., 1145 Lacampagne, A., Mercier, J., 2012. Muscle mitochondrial metabolism and calcium signaling 1146 impairment in patients treated with statins. Toxicology and applied pharmacology 259, 263-268.

1147 Song, S., Tan, J., Miao, Y., Li, M., Zhang, Q., 2017. Crosstalk of autophagy and apoptosis: 1148 Involvement of the dual role of autophagy under ER stress. J Cell Physiol 232, 2977-2984. 
1149 Staffa, J.A., Chang, J., Green, L., 2002. Cerivastatin and reports of fatal rhabdomyolysis. N Engl

1150 J Med 346, 539-540.

1151 Takeda, N., Kondo, M., Ito, S., Ito, Y., Shimokata, K., Kume, H., 2006. Role of RhoA

1152 inactivation in reduced cell proliferation of human airway smooth muscle by simvastatin.

1153 American journal of respiratory cell and molecular biology 35, 722-729.

1154 Thompson, P.D., Clarkson, P., Karas, R.H., 2003. Statin-associated myopathy. Jama 289, 168111551690.

1156 Tikkanen, M.J., Nikkila, E.A., 1987. Current pharmacologic treatment of elevated serum 1157 cholesterol. Circulation 76, 529-533.

1158 Ucar, M., Mjorndal, T., Dahlqvist, R., 2000. HMG-CoA reductase inhibitors and myotoxicity. 1159 Drug Saf 22, 441-457.

1160 Vilimanovich, U., Bosnjak, M., Bogdanovic, A., Markovic, I., Isakovic, A., Kravic-Stevovic, T., 1161 Mircic, A., Trajkovic, V., Bumbasirevic, V., 2015. Statin-mediated inhibition of cholesterol 1162 synthesis induces cytoprotective autophagy in human leukemic cells. Eur J Pharmacol 765, 4151163428.

1164 Whitehead, N.P., 2016. Enhanced autophagy as a potential mechanism for the improved 1165 physiological function by simvastatin in muscular dystrophy. Autophagy 12, 705-706.

1166 Yeganeh, B., Wiechec, E., Ande, S.R., Sharma, P., Moghadam, A.R., Post, M., Freed, D.H., 1167 Hashemi, M., Shojaei, S., Zeki, A.A., Ghavami, S., 2014. Targeting the mevalonate cascade as a 1168 new therapeutic approach in heart disease, cancer and pulmonary disease. Pharmacol Ther 143, 1169 87-110. 